\title{
Effects of Climate Change on Invasive Species
}

\author{
Deborah M. Finch, Jack L. Butler, Justin B. Runyon, \\ Christopher J. Fettig, Francis F. Kilkenny, Shibu Jose, \\ Susan J. Frankel, Samuel A. Cushman, Richard C. Cobb, \\ Jeffrey S. Dukes, Jeffrey A. Hicke, and Sybill K. Amelon
}

\subsection{Introduction}

Mean surface temperatures have increased globally by $\sim 0.7{ }^{\circ} \mathrm{C}$ per century since 1900 and $0.16{ }^{\circ} \mathrm{C}$ per decade since 1970 (Levinson and Fettig 2014). Most of this warming is believed to result from increases in atmospheric concentrations of greenhouse gases produced by human activity. Temperature increases have been greater in winter than in summer, and there is a tendency for these increases to be manifested mainly by changes in minimum (nighttime low) temperatures (Kukla and Karl 1993). Changes in precipitation patterns have also been observed, but are more variable than those of temperature. Even under conservative emission scenarios, future climatic changes are likely to include further increases in temperature with significant drying (drought) in some regions and increases in the frequency and severity of extreme weather events (IPCC 2007). For example, multimodel means of annual temperature from climate projections predict an increase of $3-9{ }^{\circ} \mathrm{C}$ in the United States

\section{M. Finch $(\bowtie)$}

U.S. Department of Agriculture, Forest Service, Rocky Mountain Research Station, Albuquerque, NM, USA

e-mail: deborah.m.finch@usda.gov

\section{J. L. Butler}

U.S. Department of Agriculture, Forest Service, Rocky Mountain Research Station, Rapid City, SD, USA

\section{J. B. Runyon}

U.S. Department of Agriculture, Forest Service, Rocky Mountain Research Station, Bozeman, MT, USA

C. J. Fettig

U.S. Department of Agriculture, Forest Service, Pacific Southwest Research Station, Davis, CA, USA

F. F. Kilkenny

U.S. Department of Agriculture, Forest Service, Rocky Mountain Research Station, Boise, ID, USA

S. Jose

College of Agriculture, Food and Natural Resources, University of Missouri, Columbia, MO, USA over the next century combined with reductions in summer precipitation in certain areas (Walsh et al. 2014). These changes will affect invasive species in several ways. Furthermore, climate change may challenge the way we perceive and consider nonnative invasive species, as impacts to some will change and others will remain unaffected; other nonnative species are likely to become invasive; and native species are likely to shift their geographic ranges into novel habitats.

The ability to predict accurately how invasive species distributions and their impacts will change under projected climate scenarios is essential for developing effective preventive, control, and restoration strategies. Climate variables are known to influence the presence, absence, distribution, reproductive success, and survival of both native and nonnative species. Environmental selection for traits that enhance reproduction in warming climates will enable range expansion of some invasive species. Also, the availability of "empty" niches in the naturalized range, an escape from natural enemies, and a capacity to adapt to new habitats can

\section{S. J. Frankel}

U.S. Department of Agriculture, Forest Service, Pacific Southwest Research Station, Albany, CA, USA

S. A. Cushman

U.S. Department of Agriculture, Forest Service, Rocky Mountain Research Station, Flagstaff, AZ, USA

\section{R. C. Cobb}

Department of Natural Resources Management and Environmental Sciences, California State Polytechnic University,

San Luis Obispo, CA, USA

J. S. Dukes

Forestry and Natural Resources and Biological Sciences, Purdue University, West Lafayette, IN, USA

J. A. Hicke

Department of Geography, University of Idaho, Moscow, ID, USA

S. K. Amelon

U.S. Department of Agriculture, Forest Service, Northern Research Station, Columbia, MO, USA 
enhance an invader's ability to respond positively to climate change (Jarnevich et al. 2014).

In this chapter, we explain how the adaptive traits, genetic variability, and physiology of certain invasive species provide them with the competitive ability to grow, reproduce, and spread successfully under conditions of climate change. Our chapter offers examples of biological responses, distributional changes, and impacts of invasive species in relation to climate change and describes how these vary among plants, insects, and pathogens, as well as by species, and by type and extent of change. We also review attributes of plants, insects, and pathogens that enhance their ability to adapt to changes in hosts, native species, and environments affected by climate change.

Our assessment of the literature reveals that, for a given invasive species at a given location, the consequences of climate change depend on (1) direct effects of altered climate on individuals, (2) indirect effects that alter resource availability and interactions with other species, and (3) other factors such as human influences that may alter the environment for an invasive species. Manipulative experiments on invasive species, while uncommon, have shown that some species respond strongly to elevated carbon dioxide $\left(\mathrm{CO}_{2}\right)$ (e.g., Dukes et al. 2011) but less so to temperature and precipitation (Dukes et al. 2011). Insects are not directly affected by elevated $\mathrm{CO}_{2}$, but they can be affected indirectly by responses of plants to $\mathrm{CO}_{2}$. However, increasing temperatures can positively affect invasive insects by influencing their movements, growth rates, phenology, dispersal, and survival. Conversely, elevated temperatures also have the potential to affect invasive insects negatively by disrupting their synchrony with their hosts and altering their overwintering environments. Climate change can directly affect invasive pathogens through effects on formation of spores, host infection success, or selection pressures. For example, some invasive pathogens are sensitive to changes in timing and amount of precipitation and to changes in ambient temperature or humidity, whereas others are more responsive to changes in host stress. Briefly, effects of climate change on pathogens vary depending on how the change is expressed and how hosts are affected.

We describe and provide examples of how indirect effects of climate change are mediated through changes in habitats, hosts, other disturbances, trophic interactions, and land use or management. Our chapter provides information on how host-invasive species relationships and trophic interactions can be modified by climate change while recognizing that important knowledge gaps remain and need to be addressed. Our review revealed that disturbances (e.g., fire, storms) associated with, or exacerbated by, climate change can result in large releases of $\mathrm{CO}_{2}$, an increase in bare ground available for invasions, and mortality of native species, all of which can potentially enhance invasive species performance.
Similarly, management practices implemented in response to effects of disturbances and climate can alter the susceptibility to invasions in positive or negative directions (Chapter 7). For example, reseeding a disturbed area after a climaterelated event with seed contaminated with an aggressive invasive plant like cheatgrass (Bromus tectorum) can unintentionally promote its spread.

This chapter covers the genetic basis of, and environmental selection on, several factors including (1) adaptive traits of invasive species, (2) evolutionary trends of invasive species in changing climates, and (3) interacting drivers and evolutionary responses of ecological communities to invasion. Climate change and invasive species are drivers of global environmental change that interact across biological communities in ways that have eco-evolutionary consequences. Successful invasions are dependent on the genetic makeup of a species. High levels of additive genetic variation tend to be linked to successful invasions (Crawford and Whitney 2010) and the ability of an invader to evolve in response to novel environments or changing conditions. Rapid adaptation to local climates can facilitate range expansions of invasive species (Colautti and Barrett 2013), even beyond the climatic distributions in their native ranges (Petitpierre et al. 2012).

We discuss and provide examples of how and why carbon cycling and carbon storage change, their relationship with insect outbreaks, and how climate can influence those changes. Insect and disease outbreaks can affect ecosystemlevel carbon cycling and storage by reducing growth, survival, or distribution of trees. Under climate change, invasive organisms are likely to vary in their impact and rate of spread, depending on their sensitivities to climate variation and on the extent and type of climate change.

In order to manage invasive species under a changing climate, it is important to anticipate which species will spread to new habitats and when, and to understand how the characteristics of specific invaders may disrupt or have the potential to disrupt invaded ecosystems. Of utmost importance in containing the spread of invasive species, managers must have the ability to (1) predict which species will positively respond to climate change, (2) predict and detect sites likely to be invaded, and (3) deter incipient invasions before they are beyond control. We outline methods for developing the capability to predict and monitor invasive species in order to forecast their spread and increase their detection. Key findings and key research needs are included for each section.

\subsection{The Influence of Climate Change on Invasive Species Distributions}

At large spatial scales, climate variables are considered to be the dominant factors influencing species presence or absence (Thuiller et al. 2007). Relating climatic conditions to occur- 
rence data is a widely used biogeographic approach to describe contemporary species distributions (Pearman et al. 2007; Peterson 2011) and for predicting how climate change may impact distributions (Guisan et al. 2014; Jeschke and Strayer 2008). The basic approach to predicting the potential geographic distribution of invasive species in their naturalized range involves developing statistical models that describe their native range in relation to climatic variables (their climatic niche) and then applying the models to the naturalized range (Broennimann and Guisan 2008; Early and Sax 2014; Jeschke and Strayer 2008). It is generally assumed that climatic models of native range distributions reflect interactions with nonclimatic factors (competition, predation, parasites, dispersability, edaphic factors, etc.) (Pearman et al. 2007).

The ability to predict the future distribution of invasive species in response to climate change is a complicated task, considering that numerous factors influence local and short-term patterns of invasion (Mainali et al. 2015), and because invasive species and concurrent climate and landuse changes are dynamically linked (Bellard et al. 2013; Smith et al. 2012). This is a linkage that already represents a significant component of global change (Vitousek 1994). At the broadest level, climate change may create conditions that favor the introduction of new invasive species into habitats where suitability was improved while altering local distribution and abundance of existing invasive species (Hellmann et al. 2008; Walther et al. 2009). Climate change is also likely to modify competitive interactions, resulting in native communities that are more or less susceptible to colonization by new invaders or expansion by established invaders. If the competitive ability of primary invaders is lessened by climate change, the ecological and economic impact of the invader may be reduced to the point where it would no longer be considered invasive (Bellard et al 2013; Bradley et al. 2010; Pyke et al. 2008). Conversely, climate change-induced interchange of biotic interactions may also expedite the conversion of benign, resident nonindigenous species to invaders (Richardson et al. 2000). Climate change could also facilitate the increased abundance of secondary invaders by reducing the competitive ability of the primary invader or by altering the effectiveness of management strategies (Pearson et al. 2016). The significance of secondary invasions is increasingly being recognized, and it may arise either from invasive species subordinate to primary invaders (Pearson et al. 2016) or from the pool of nonindigenous species that often co-occur with the primary or secondary invaders (Kuebbing et al. 2013). Collectively, if climate change increases the abundance and distribution of some invasive species while decreasing or converting others, the net result may be no change in species richness of either invasive or nonnative species (Hellmann et al. 2008).

\subsubsection{Altered Pathways for Invasive Species Introductions}

Climate change will almost certainly alter pathways for the movement of invasive species on a global scale (Walther et al. 2009). During the invasion process, potential invasive species must successfully pass through a variety of environmental filters (Theoharides and Dukes 2007). However, invasive species must first overcome major geographic barriers to their spread, which is currently facilitated largely by human activities (Lehan et al. 2013) and likely will be enhanced under climate change (Pyke et al. 2008; Seebens et al. 2015). Many existing and potential invasive species spread into new areas as stowaways in and on cargo ships (in cargo holds, containers, or ballast water; as contaminants in agricultural crops; or on ships hulls) (Hulme 2009). In the United States, current inspection of cargo ships for invasive species involves examining a small percentage of cargo imports for a small subset of federally listed species while leaving the vast majority unchecked; some of these overlooked species could potentially become invaders under a scenario facilitated by climate change (Lehan et al. 2013).

Global warming is reducing the extent and thickness of sea ice, resulting annually in more open water for longer periods of time (Liu et al. 2013; Stroeve et al. 2012). For invasive species that may arrive as stowaways, reductions in ice pack affecting both oceanic and freshwater shipping routes have globally extended shipping seasons while reducing travel time for cargo ships; this will likely increase survival rates of propagules and potentially enhance the probability of establishments in the new range (Pyke et al. 2008). Loss of sea ice has also increased the frequency and ease of movement of marine birds and mammals between the Pacific and Atlantic Ocean basins (McKeon et al. 2016). This could enhance long-distance dispersal of many sessile organisms (Viana et al. 2016) that potentially could become invasive in newly created suitable climates in the invaded range. Additionally, migration times of birds have been shown to be impacted by climate change (see review by Miller-Rushing et al. 2008), which may play a role in expanding the distribution of aquatic invasive species carried by avian vectors (Coughlan et al. 2015; Reynolds et al. 2015).

Another mechanism for short- and long-term dispersal of invasive species is the increased frequency, intensity, and duration of extreme weather events that are correlated with climate change (IPCC 2007; Melillo et al. 2014). Hurricanes and other strong winds can carry invading propagules, insects, marine larvae, and birds; reduce existing vegetation; and create bare soil, enhancing opportunities for colonization (Michener et al. 1997; Richardson and Nemeth 1991; Schneider et al. 2005; Walther et al. 2009). Frequent and more expansive flooding associated with climate change would likely increase connectivity among different habitats for invasive species, although this pathway has received little attention. 
There is a 400-year history of importing and cultivating introduced grasses, forbs, shrubs, and trees into the United States for ornamental or agricultural purposes (Mack and Erneberg 2002; Reichard and White 2001). Although the vast majority of the plants intentionally introduced are not invasive (Reichard and White 2001), deliberate introductions are the primary source of invasive plants, especially for trees and shrubs, in the Eastern United States (Lehan et al. 2013). The risk of ornamentals escaping and becoming invasive escalates among an increasingly urbanized and affluent population that has an aversion for ornamental lawns and gardens (Marco et al. 2010). This is compounded by minimal legal restrictions to oversee the introduction of plants into the United States (Reichard and White 2001), and a complete disconnect between the financial benefit realized by the horticultural industry from selling imported plants and the economic and ecological costs attributed to escaped ornamentals that become invasive (Barbier et al. 2011). Typically, plants selected for introduction for ornamental or agricultural purposes have broad climatic tolerances and phylogenetic traits that favor their rapid establishment and growth, thus enhancing their potential for invasiveness in response to climate and land-use changes (Bradley et al. 2010). Likewise, under climate change, the demand for introduced plants that can better tolerate drought and high temperatures is likely to increase (Bradley et al. 2012), which will dramatically increase propagule pressure of potential invasive species (Lockwood et al. 2005). Meanwhile, native plants may experience "migration lag" to climate change (sensu Corlett and Westcott 2013), which is likely to put them at a competitive disadvantage, thereby creating vegetation gaps potentially filled by introduced species. Increased introductions of phenotypically plastic, preadapted, nonnative species (Turner et al. 2015), coupled with a lag in native species migration (Corlett and Westcott 2013), are likely to lead to the creation of novel communities that possess unknown ecological characteristics (Bernard-Verdier and Hulme 2015).

Even without considering the effects of global change on invasive species distributions, humans have deliberately or accidentally moved thousands of species beyond their native ranges.

Published estimates of the number of introduced species in the United States range from 4000 (Stein and Flack 1996) to 5000 species (Morse et al. 1995). Currently, only a small fraction of the pool of introduced species is classified as invasive, defined as adversely impacting native species, communities, and ecosystems (Hiebert 1997; Skinner et al. 2000). However, it is proposed that climate change will enhance and accelerate pathways for new introductions and, thus, dramatically increase the risk of invasion by potentially damaging species (Bradley et al. 2012; Hellmann et al. 2008). Developing the proficiency to predict which species will successfully emerge among the next wave of invaders is the subject of increased experimental research and species distribution modeling. Published literature on the impact of climate change on invasive species distribution has increased substantially since 2000, and most is focused on North America (see review by Smith et al. 2012).

\subsubsection{Distribution Changes During Invasion}

The tendency of invaders to inhabit similar climatic niches in both the native and introduced ranges was confirmed in a large-scale survey of 50 terrestrial plant invaders (Petitpierre et al. 2012). However, other studies have shown that invasive species are able to successfully establish and reproduce in climates different from those found in their native range (Beaumont et al. 2009; Bradley et al. 2015; Broennimann et al. 2007). Incorporating multiple-scale climatic, biotic, and land-use variables into distribution models can improve the models' performance in predicting changes in the distribution of invasive species in response to future climates (Jarnevich et al. 2014; Pearson and Dawson 2003), especially if monitoring data were available to validate prediction models (Jones 2012; Sheppard et al. 2014; Smith et al. 2012).

While many species distribution models can successfully predict areas of potential introduction, the lack of nonclimatic data in these models often inhibits their ability to predict the total extent of invasion in the naturalized range (Bradley et al. 2015). For example, Broennimann et al. (2007) reported a dramatic climatic niche shift for spotted knapweed (Centaurea maculosa), an aggressive plant invader in Western North America. However, nonclimatic factors, especially lack of natural enemies in the native range, may play a major role in the climatic expansion of invasive plants, as observed with spotted knapweed (Corn et al. 2006; Maines et al. 2013; Seastedt et al. 2007; Story et al. 2006).

Once established in a community, invasive species, along with native and nonnative constituents, must track future climate change in order to survive (Corlett and Westcott 2013). The consequences of not doing so may be less severe for invasive species than for native species because of partial or total release of abiotic and biotic constraints. The availability of empty niches in the naturalized range, coupled with adaptive plasticity and evolutionary changes, can enhance the ability of invasive species to shift into new habitats and climates (Higgins and Richardson 2014; Jarnevich et al. 2014; Kumschick et al. 2013; Turner et al. 2015). However, documenting evolutionary niche shifts is likely only possible when invasive species have occupied their naturalized ranges for relatively long periods of time. Broennimann et al. (2007) suggested that for spotted knapweed, this period is likely greater than 120 years, although the timeframe is probably strongly influenced by propagule pressure driven by multiple introductions (Lockwood et al. 2005). 


\subsubsection{Interacting Drivers of Global Environmental Change and Evolutionary Responses of Native Ecological Communities to Invasion}

Interactions between species play an important role in structuring ecological communities, and these interactions are often climate dependent (Dunson and Travis 1991; Norberg 2004). A review of 688 published studies showed that drivers of global environmental change, including climate change and species invasions, are likely to influence virtually every type of species interaction across all terrestrial ecosystems (Tylianakis et al. 2008). Due to the immense complexity of global ecological communities, it is extremely difficult to decipher the higher order effects of interactions between drivers of environmental change, which can both mitigate and exacerbate one another. However, Tylianakis et al. (2008) were able to glean some generalities across terrestrial ecosystems, indicating that these drivers will generally (1) reduce the strength of positive mutualisms (i.e., where two species benefit in a relationship) involving plants, such as seed dispersal and pollination; (2) have effects on soil food webs that will shift ecosystem process rates, including for beneficial ecosystem services; (3) change the relative abundance and dominance of all taxa across ecological networks; (4) increase herbivory rates from all animal taxa, which will be mitigated only by variable levels of attack by predators or parasites; and (5) lead to a higher frequency and severity of pathogen effects on plants and animals across ecosystems.

Theoretical and applied models are being developed to help disentangle and better predict the effects of multiple drivers of global change on ecological communities (Gilman et al. 2010). However, few of these models take into account the effect of evolution on ecological interactions. Invasion by nonnative species can act as a novel and strong selective pressure for native species that compete with invaders for resources or interact with them in other ways (Leger and Espeland 2010). Native species that survive initially aggressive invasions are likely to compete with the invaders and enter into coevolutionary feedback loops. For example, some populations of the red-bellied black snake (Pseudechis porphyriacus) in Australia, a predator that has suffered population declines due to invasion of the cane toad (Bufo marinus), and therefore faces strong selection pressure, have evolved a physiological tolerance to cane toad toxin, which is normally lethal (Phillips and Shine 2006). In another example, invasive giant hogweed (Heracleum mantegazzianum) became less dominant in Eastern European sites that had been invaded the longest ( $\sim 30$ years); common garden soil inoculation experiments indicated that negative plant-soil feedbacks may be responsible, possibly through the evolution of soil microbiota (Dostál et al. 2013). Knowledge of the evolutionary responses of native species to invaders can help us better understand how ecological communities might resist invasion. To gain insight, novel models of resistance and resilience will need to be constructed that take into account the potential impact of climate change on eco-evolutionary processes.

As invasive species populations expand in space (overcoming geographic barriers) and time (under climate change), they are exposed to novel environments and, therefore, subject to different selection pressures as compared to those that occur in their native ranges (Mooney and Cleland 2001). Rapid adaptation to novel environments can provide both native and introduced species opportunities for expansion under a changing climate (Barrett 2000); however, introduced species that have escaped their natural enemies may have a competitive advantage (Blossey and Nötzold 1995), thus increasing their likelihood for spread. Furthermore, evidence indicates that populations of some invasive species may arrive in their introduced range preadapted to conditions extant in the new range. For example, spotted knapweed occurs as both diploid and tetraploid cytotypes in its native range in Europe, but currently, only the tetraploid cytotype has been reported in its introduced range in North America (Mráz et al. 2014). The tetraploid cytotype has higher drought tolerance than the diploid cytotype (Mráz et al. 2014), which might contribute to its successful invasion success in Western North America where severe drought frequently occurs.

Preadaptation, genetic variation, hybridization, and multiple introductions provide the raw material that allows introduced populations to adapt rapidly to broad-scale and dynamic environmental conditions. Kumschick et al. (2013) reported that invasive common mullein (Verbascum thapsus) has evolved into a fast-growing phenotype with a strong response to a wide array of abiotic conditions, with and without competition. This may provide a competitive advantage in environments where precipitation is variable. Similarly, Turner et al. (2015) found that populations of diffuse knapweed (Centaurea diffusa) that occurred in its introduced range were genetically and phenotypically different from populations existing in its native range. The collective evidence indicates that environmental selection for genotypes that can grow and reproduce under broad climatic conditions will provide opportunities for existing invasive species to expand eventually into a greater diversity of environments.

\subsubsection{Key Findings}

Invasive species tend to have high dispersal rates, rapid growth rates with short generation times, and high capacity to tolerate broad environmental conditions. Collectively, these traits greatly enhance their ability to cope with rapid changes in abiotic and biotic conditions such as those associated with climate change. When these traits are compounded by the existence of ineffective international trade regula- 
tions, climate change-induced alterations in geographic barriers, temperature and moisture constraints, and biotic interactions, considerable evidence suggests that climate change will almost certainly lead to changes in the distribution of invasive species. Predicting how invasive species will respond under predicted climate change scenarios is a serious challenge but essential to developing effective strategies for preventing and controlling invasive species and for restoring invaded habitats.

An extensive review showed that drivers of global environmental change will influence every type of species interaction across all terrestrial ecosystems. Theoretical and applied models are being developed to help disentangle the effects of multiple drivers of global change on ecological communities, but few of these models take into account the effect of evolution on ecological interactions. Native species that survive initially aggressive invasions are likely to compete with the invaders and enter into coevolutionary feedback loops.

\subsubsection{Key Information Needs}

Current guidelines for detecting and managing new and existing invasive species that have the potential to spread have limited applicability under scenarios that include climate and land-use changes. Research is needed that evaluates population- and landscape-level responses of invasive species to multiple spatial and temporal stressors and disturbances when they are operating simultaneously (e.g., extreme climatic events in relation to increased global commerce and changes in fire regimes). The ability to project accurately how future invasive species distributions respond to climate change is usually enhanced when ensembles of climate envelope models are used in conjunction with multiple climate change scenarios. Field evaluation of predictions is essential for improving model performance. Understanding the evolutionary responses of native species and species assemblages to invaders can help us understand how ecological communities might respond to invasion.

Theoretical models on interacting drivers of global change, including changing climates and invasive species, need to incorporate explicitly the influence of evolutionary processes. Extensive research will be necessary to explain coevolutionary feedback loops between native communities and invaders, specifically in the context of climate change.

\subsection{Adaptive Responses of Invasive Species to a Changing Climate}

One of the lessons learned from evolutionary biology is that evolutionary processes, such as natural selection and genetic drift, often happen at ecologically relevant time scales
(Carrol et al. 2007) and that these evolutionary processes can drive change over only a few generations, often well within a human lifetime (e.g., Kilkenny and Galloway 2013; Phillips et al. 2006). When environmental fluctuations occur within a narrow time frame, as with normal year-to-year variation, directional evolutionary shifts tend to counteract one another so that characteristics of species and populations remain relatively stable for long periods (Grant and Grant 2002). However, when the biotic or abiotic environment that a species experiences moves beyond stable boundaries, either through prolonged directional change or increased variability, then long-term evolutionary changes are likely to occur (Carrol et al. 2007). Climate change and invasive species are drivers of global environmental change that are likely to interact across ecological communities in ways that will have long-lasting eco-evolutionary impacts.

\subsubsection{Selection on Adaptive Traits and Evolutionary Trends in Changing Climates}

Phenotypic variation in climate adaptation can arise across a species' invaded range during the invasion process. As individuals move into new areas, selection is expected to operate on traits by favoring individuals that can thrive under local biotic and abiotic conditions (Parker et al. 2003). For example, a number of studies have shown that invasive plant species can adapt rapidly to local conditions along environmental clines that can be regional or range wide (e.g., Alexander et al. 2009; Kooyers and Olsen 2012; Maron et al. 2004). Rapid adaptation to local climates can facilitate range expansion and overcome early environmental constraints on propagule production (Colautti and Barrett 2013). Indeed, adaptation to local environments can facilitate invasive species expanding into areas that possess novel environmental conditions that they did not experience in their native habitats (Broennimann et al. 2007). A comprehensive meta-analysis showed that $15 \%$ of invasive species show evidence of range shifts that are significantly outside the climatic distributions in their native ranges (Petitpierre et al. 2012). While the authors of this meta-analysis considered $15 \%$ to be "rare," it nevertheless suggests that a large number of invasive species are adapting to novel climate conditions and may continue to do so. For example, ongoing adaptation of populations of the invasive vine Japanese honeysuckle (Lonicera japonica) at the margin of its expanding northern range in Eastern North America suggests that this species will continue to spread under changing climatic conditions (Fig. 4.1; Kilkenny and Galloway 2016).

Similar selection pressures may be operating for plant species such as Lehmann lovegrass (Eragrostis lehmanniana), which was introduced for agricultural purposes. 
Fig. 4.1 Predicted juvenile winter survival of Japanese honeysuckle (Lonicera japonica) by latitude under recent climate normals (1961-1990) and a consensus of future climate scenarios for 2050 (scenario A2 for CCCMA, CSIRO, and HADCM3) for populations sourced from the core and margin of the invaded range (From Kilkenny and Galloway 2016)

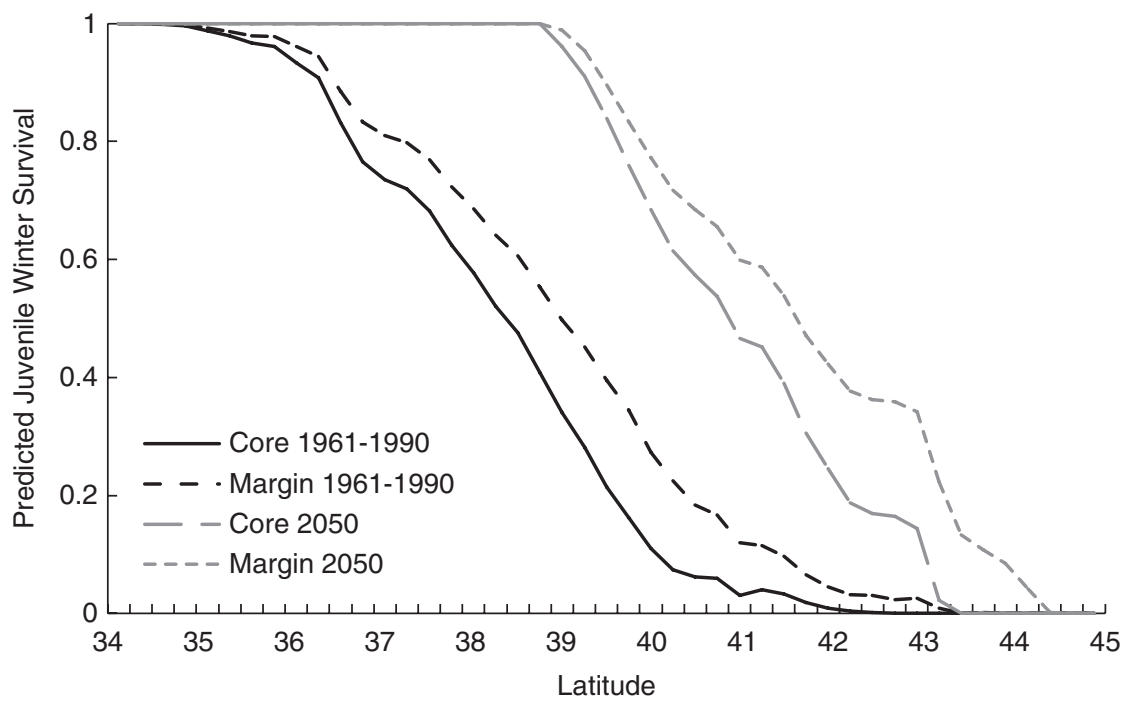

Lehmann lovegrass was selected and introduced specifically for its drought tolerance, which likely will favor its success in drier conditions that are projected for the Southwestern United States (Archer and Predick 2008). The primary expansion of buffelgrass (Pennisetum ciliare), another neotropical species introduced in the Southwestern United States, began during the warmer winters in the 1980s, and buffelgrass continues to expand upslope with increasing winter temperatures (Archer and Predick 2008). Similar expansions of buffelgrass are predicted to occur in Australia under a climate change scenario (Martin et al. 2015).

The process of invasion and range expansion can select for traits that promote colonization itself, such as those that enhance dispersal (e.g., Lombaert et al. 2014), enhance interspecific competition (e.g., Lankau et al. 2009), or promote more rapid reproduction (e.g., Kilkenny and Galloway 2013). Dispersal traits may be particularly important, because individuals with the greatest dispersal abilities are more likely to initiate new populations, which can lead to "spatial sorting" (Travis and Dytham 2002) and widespread selection on dispersal traits across the expansion front (Chuang and Peterson 2016).

Theoretical studies indicate that selection based on dispersal ability and adaptation to local climates will likely interact in complex ways under changing climates. Hargreaves et al. (2015) demonstrated that dispersal ability is generally only favored in situations where dispersal has little to no direct fitness costs, such as low survival of longdistance dispersers, regardless of whether the climate is stable or changing. However, when local adaptation is taken into account, the situation becomes more complex. In a stable climate, local adaptation will limit selection based on dispersal ability, even if there are no other direct fitness costs. But in a changing climate, local adaptation may enhance selection for dispersal ability even if it does result in some fitness costs because populations or ecotypes are likely to be at an advantage if they can spatially track the climates they are most adapted to.

While the occurrence of adaptive processes is widespread during invasions, repeated founder events can drive nonadaptive evolution and mimic some of the patterns characteristic of climatic adaptation (Keller and Taylor 2008). This is because founding propagules are more likely to establish in climates similar to those that match their source environment. Therefore, what appears during an invasion to be adaptive evolution may simply reflect sampling processes that have led to the foundation of invading populations that contain preadapted genotypes (Keller et al. 2009). Understanding how adaptive and nonadaptive processes contribute to the distribution of an invasive species may be critical in predicting how that species might spread under climate change, because this balance can affect future evolutionary potential.

\subsubsection{Key Findings}

Evolutionary processes can drive rapid change in species but tend to cancel out over time under stable environmental conditions. When the environments are no longer stable, longterm evolutionary change is more likely. Drivers of global environmental change are likely to interact in ways that will produce long-lasting eco-evolutionary impacts.

As species invade new areas, natural selection will favor individuals that can thrive under biotic and abiotic conditions common to the new habitat. As much as $15 \%$ of all invasive species are adapting to climate conditions that they never experienced in their native ranges. The process of invasion can select for traits that promote colonization, including traits that enhance dispersal and rapid establishment. 
Theoretical studies indicate that selection on dispersal ability and adaptation to local climates will likely interact in complex ways under changing climates. Repeated founder events can drive nonadaptive evolution during invasions and can mimic some of the patterns of climatic adaptation.

\subsubsection{Key Information Needs}

Research is needed to determine how and to what extent climate change acts as a selection process on invasive species. Acquiring knowledge on the interaction between climate change and genetic processes such as hybridization and polyploidization will be essential to our ability to predict how invasive species adapt to climate change. Understanding how climate change influences natural selection on invasive species undergoing range expansion, including selection on dispersal traits, will improve our ability to manage spreading populations effectively.

\subsection{Impacts of Climate Change on Physiology, Survival, Productivity, Phenology, and Behavior of Invasive Plants, Insects, and Pathogens}

\subsubsection{Impacts on Invasive Plants}

Changes in the climate and atmosphere are provoking a wide variety of responses from invasive plants (for in-depth reviews, see Blumenthal and Kray 2014; Bradley et al. 2010; Dukes 2011; Leishman and Gallagher 2016). The consequences of climate change for a given plant species at a particular location depend on three types of mechanisms: direct effects of climate change that alter physiology, growth, and survival; indirect biological effects that alter resource availability, competition, herbivory, disease, and resistance to human management; and indirect societal effects that may alter the value of resources affected by the invasive species, and thus the degree to which the species is subjected to human management. In a given location, any one of these mechanisms may have the greatest influence. These localscale concerns, though, occur in the context of the larger landscape; propagules of species (including the invasive species) move around, and the composition of communities can change with time. These changes also have consequences for invasive plant species.

At a basic level, many studies have examined the direct effects of climate and atmospheric change on a variety of invasive plant species grown in isolation (Dukes 2000; Leishman and Gallagher 2016; Sorte et al. 2013; Verlinden and Nijs 2010; Ziska and Dukes 2011). Elevated $\mathrm{CO}_{2}$ generally favors invasive plants, though not necessarily much more than natives, and changes in warming and precipitation can favor or disfavor them, depending on the magnitude of change (and in the case of precipitation, the direction of change as well). However, in natural and managed ecosystems, these direct effects do not occur in isolation. Field manipulations in which both the invasive plants and their surrounding communities experience simulated future conditions unavoidably include at least some of the indirect biotic effects that will influence the success of invasive species. Relatively few of these studies have been conducted, but some show strong responses, such as those of the invasive forbs yellow star-thistle (Centaurea solstitialis L.) (Dukes et al. 2011) and Dalmatian toadflax (Linaria dalmatica (L.) Mill.) (Blumenthal et al. 2013), to elevated $\mathrm{CO}_{2}$ in annual grassland and mixed-grass prairie, respectively. No realistic studies of this type have been conducted on invasive trees, but an invasive shrub responded positively to elevated $\mathrm{CO}_{2}$ (Belote et al. 2003) in a forest plantation in Tennessee. Such responses may depend on other conditions, such as soil moisture (Smith et al. 2000). The response of invasive species to warming and precipitation manipulations have generally been less dramatic than their responses to $\mathrm{CO}_{2}$ (e.g., Blumenthal et al. 2013; Dukes et al. 2011; Maron and Marler 2008), but precipitation changes can sometimes have important consequences in concert with other environmental or biological factors (Blumenthal et al. 2008; Suttle et al. 2007).

Potential responses of species' distributions to changes in mean climatic conditions can be predicted using a variety of habitat suitability models; these models have been applied to a growing number of invasive plant species (Bradley 2014). Distributions of invasive plant species are generally projected to expand outward from the current colder edges of their habitat and shift away from the warmer edges, leaving potential opportunities for preemptive restoration (Bradley and Wilcove 2009). However, these models make a variety of assumptions and only provide predictions of potential range - the expansion of species into these ranges would depend on numerous other factors.

Recent evidence indicates that many invasive species occupy unique phenological niches and track climate change more closely than native species (Willis et al. 2010; Wolkovich and Cleland 2011, 2014; Wolkovich et al. 2013). Willis et al. (2010) discussed how phenological flexibility and the existence of vacant niches may contribute to the success of nonnative species under conditions of climate change, because those species with the most flexible phenologies also flowered earlier than native plants that had not responded to earlier warming. In a study across five North American sites, Wolkovich et al. (2013) found that nonnative species shifted flowering in relation to climate change while native species, on average, did not. They also reported that in mesic systems, invasive species exhibited greater tracking of interannual variation in temperature than did native species, while 
in grasslands, invasive species differed from native species primarily in their responses to precipitation and soil moisture but not to temperature. Their findings provide cross-site support for explaining the role of phenology and climate change and possibly for predicting species invasions. In addition, because climate change may alter the timing and severity of ecosystem stress and disturbance, it could provide unique opportunities for invasion (Fig. 4.2) (Wolkovich and Cleland 2014). Based on experimental manipulations of climate change, Wainwright et al. (2012) suggest that managers might be able to trick phenotypically plastic invasive plants into germinating earlier than appropriate for the local climate, resulting in reduced survivorship, but this is yet to be demonstrated at large scales.

Recipient plant communities will likely become more susceptible to climate change (through a reduction of the biotic resistance of the communities) as the climate becomes less optimal for resident species (Dukes and Mooney 1999) and as extreme events become more frequent and more disruptive to the resident community (Diez et al. 2012). Because many invasive species are able to disperse rapidly over long distances, they may be able to rapidly colonize areas with lowered resistance, such as those disturbed by extreme events. The relatively broad climatic tolerances found in many invasive species (Bradley et al. 2015) may confer greater tolerance to changing climatic conditions than what is typically observed in native species.

The effectiveness of techniques for managing some invasive plant species may be affected by climate and atmospheric changes (Ziska and Dukes 2011). When exposed to enriched $\mathrm{CO}_{2}$, some invasive plants became more tolerant to the widely used herbicide glyphosate (Manea et al. 2011; Ziska et al. 2004). Biocontrol species may also be affected by climate change, thus potentially altering their effectiveness (Hellmann et al. 2008).

Finally, as climatic disruption progresses, the management of invasive plant species may change (Dukes 2011), either because they are considered to be more harmful under climate change, for example, if they are perceived to deplete a resource such as water that increases in value, or because they are perceived to have greater value, for example, if they are selected to be grown for bioenergy.

\subsubsection{Impacts on Invasive Insects}

The physiology of insects is highly sensitive to temperature and climate warming, and thus climate change is predicted to be largely beneficial to invasive insects, as least directly (Bale et al. 2002; Deutsch et al. 2008). Warming tempera-

\begin{tabular}{|c|c|c|}
\hline $\begin{array}{l}\text { Previous climate } \\
\text { (high variability) }\end{array}$ & $\begin{array}{c}\text { Previous climate } \\
\text { (low variability) }\end{array}$ & $\begin{array}{l}\text { Previous climate } \\
\text { (high variability) }\end{array}$ \\
\hline $\begin{array}{l}\text { Shifted climate } \\
\text { (high variability) }\end{array}$ & $\begin{array}{l}\text { Shifted climate } \\
\text { (low variability) }\end{array}$ & $\begin{array}{l}\text { Shifted climate } \\
\text { (high variability) }\end{array}$ \\
\hline 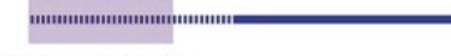 & & 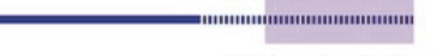 \\
\hline $\begin{array}{l}\text { High potential for } \\
\text { invasions }\end{array}$ & & $\begin{array}{l}\text { High potential for } \\
\text { invasions }\end{array}$ \\
\hline
\end{tabular}

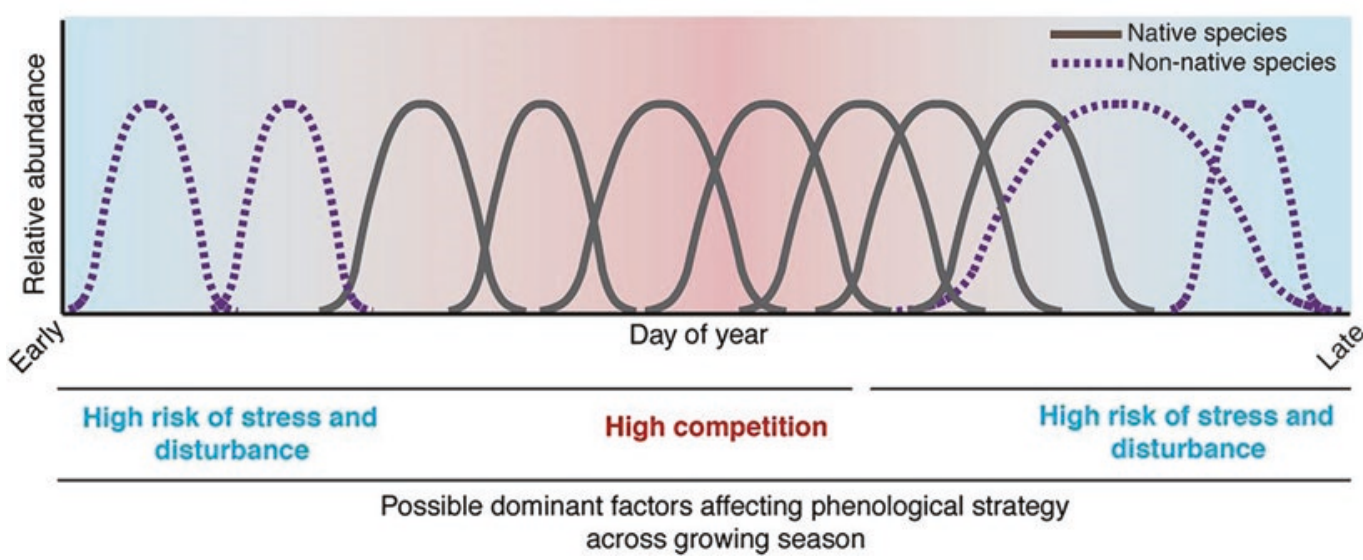

Fig. 4.2 Conceptual model of a hypothesized mesic temperate system showing idealized niche diagrams for four nonnative species (dashedline distributions) and seven native species (gray distributions) where temperature limits viable periods for plant growth. Variation in stress, disturbance, and competition may dictate optimal phenological strate- gies, with benefits for early- and late-flowering invasive species. With climate change extending viable periods for plant growth (dark blue lines), nonnative species with highly plastic phenologies may have an increased opportunity for invasion at the start and end of the growing seasons (From Wolkovich and Cleland 2014) 
tures tend to increase insect movement, feeding rate, growth rate, dispersal, and survival (Bale et al. 2002), but very high temperatures can sharply reduce fitness of insects (Deutsch et al. 2008). The distribution and abundance of insects respond quickly to climatic change owing to insects' high mobility, short generation time, physiological sensitivity to temperature, and high reproductive potential (Weed et al. 2013). For example, the distribution of the invasive hemlock woolly adelgid (Adelges tsugae) in the Eastern United States is currently limited by cold winter temperatures; but predicted future warming could allow hemlock woolly adelgid to spread unchecked throughout the range of hemlock (Tsuga spp.) in North America (Dukes et al. 2009). Additionally, climate affects tree defenses, tree tolerance, and community interactions involving enemies, competitors, and mutualists of insects and diseases (Weed et al. 2013).

Warming could negatively affect invasive insects, on the other hand, by disrupting developmental synchrony with their host plants (Bale et al. 2002; see biocontrol discussion in Sect. 4.7.2). Moreover, negative effects can occur if warming leads to a reduction of insulating snow cover, thus exposing overwintering life stages to freezing conditions (Bale and Hayward 2010). There is evidence that periods of extreme winter warm snaps followed by extreme cold can kill emerald ash borer (Agrilus planipennis) larvae (Sobek-Swant et al. 2012). Despite the great influence of temperature on insects, we still cannot confidently predict how climate warming will affect most invasive species.

Unlike plants, insects are not directly affected by elevated $\mathrm{CO}_{2}$ (Guerenstein and Hildebrand 2008); but insects, especially herbivores, can be indirectly affected through responses of plants to $\mathrm{CO}_{2}$. For example, most plants grown under a regime of elevated $\mathrm{CO}_{2}$ have a higher carbon-to-nitrogen ratio in their tissues which dilutes nutrient content, most notably nitrogen which is a factor that usually limits growth of insects (Coviella and Trumble 1999). As a result, insects must consume more plant tissue to obtain enough nutrients for growth and development (Cannon 1998; Coviella and Trumble 1999; Dermody et al. 2008; Johnson and McNicol 2010). However, in some forests, the amount of insect feeding can be reduced under elevated $\mathrm{CO}_{2}$ (Knepp et al. 2005). Plant secondary chemistry - a central factor regulating herbivore growth and survival - can be affected by most climate change factors, including elevated $\mathrm{CO}_{2}$, temperature, ozone $\left(\mathrm{O}_{3}\right)$, drought, and ultraviolet (UV) light (Bidart-Bouzat and Imeh-Nathaniel 2008; Burkle and Runyon 2016; Jamieson et al. 2017; Kolb et al. 2016; Yuan et al. 2009). A plant's ability to enact chemical defenses in response to feeding by invasive herbivores can also be altered by climate change (Zavala et al. 2008). However, information available on climateinduced changes in plant chemistry is limited, and the response (increase, decrease, or no effect) is dependent on the plant species involved as well as the class of chemicals examined (Bidart-Bouzat and Imeh-Nathaniel 2008; Lindroth 2010). Additionally, the response to climate change varies with herbivore species. A recent meta-analysis found that in response to elevated $\mathrm{CO}_{2}$, the abundance of some arthropod herbivore groups increased (e.g., mites and thrips) whereas others decreased (e.g., Lepidoptera and leaf miners) (Robinson et al. 2012). These highly context-dependent and species-specific findings have hindered our attempts to identify general patterns.

\subsubsection{Impacts on Invasive Pathogens}

There are numerous microbes that are considered to be serious pathogens of ecological communities, and several factors, that is, their small physical size, cryptic symptoms, and poor detection methods, have contributed to rapid and extensive invasions. Invasive microbes are among some of our most destructive forest pathogens, and most of them were initially introduced or their spread was facilitated by outplanting of infected nursery stock, international plant trade, or poor nursery cultural practices (Anagnostakis 1982; Maloy 1997; Rizzo et al. 2005). While there is a clear need and strong desire to improve cultural practices in the nursery industry to reduce pathogen invasions (Brasier 2008), there is also an inescapable need to understand why some of the many established pathogens eventually emerge as disease agents or suddenly expand into new locations and hosts. In our effort to understand the interaction of invasive pathogens with climate change, it is important to distinguish the condition (disease) from the biological agents (pathogens) involved. The emergence of disease can almost always be framed as a three-way interaction among pathogens, their hosts, and the environment (Fig. 4.3). This disease triangle, sometimes expanded to include the effects of management, can be used to demonstrate how environmental change can affect pathogens and thereby disease (Alexander 2010).

Climate change can directly affect pathogen populations by controlling sporulation, affecting the likelihood of successful infection, or imposing selection on pathogen popula-

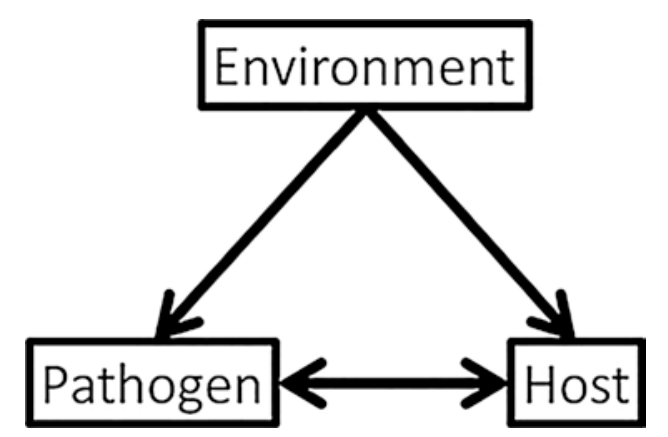

Fig. 4.3 The three-way interactions of the disease triangle 
tions for certain phenotypic characteristics (Davidson et al. 2008; Eyre et al. 2013; Woods et al. 2005). Over the last decade, extensive and severe drought has been a major focus of research and management in forests of Western North America (Vose et al. 2016); while our understanding of drought-pathogen interactions is notable for many uncertainties (Desprez-Loustau et al. 2006; Kolb et al. 2016; Sturrock et al. 2011), broader climate change such as changes in temperature or the timing and type of precipitation (rain vs. snow) can also alter host-pathogen relationships in ways that foster disease emergence (Sturrock et al. 2011). Fungi are without doubt the most important group of forest pathogens and are very sensitive to the timing and quantity of precipitation, ambient temperature, relative humidity, and other factors that influence leaf surface or soil moisture (Davidson et al. 2008; Meentemeyer et al. 2011; Woods et al. 2005). Because fungi are such a diverse group of microbes, it is essential to evaluate each fungus-caused disease problem on a case-by-case basis. For any analysis of risk or threat posed by invasive pathogens, the specific biology of each organism is critical in determining how climate change will interact with each respective organism. Unfortunately, that biological understanding is weak for many important groups of damaging fungal microbes (Hansen 2015). This has led to a number of ecological surprises where a pathogen was thought to be insignificant in one environment but was very destructive in another. This can be due to congeneric hosts in the new environment but also due to direct effects of environmental change. Where climate change increases the sporulation, growth rate, or survival of individual pathogens, it is possible that unanticipated disease epizootics can occur. For example, when shifts in precipitation forms (greater precipitation in rain vs. snow) occur, foliar pathogen outbreaks can be unprecedented (Woods et al. 2016). Unplanned, natural experiments using nonnative timber species planted in environments warmer or wetter than their native range can also result in unexpected pathogen outbreak, sometimes with devastating impacts to timber resources (Brasier and Webber 2010).

The effects of climate change on pathogen-caused diseases can also be facilitated indirectly by their effect on host plants. Plant stress resulting from decreased carbon reserves or loss of hydraulic function (Adams et al. 2009; Anderegg et al. 2012; Hartmann et al. 2013) can alter plant defensive responses in ways that can increase plant susceptibility to infection and possibly enhance subsequent spread (Bostock et al. 2014). Different plant pathogens impact different plant parts and utilize varying modes of infection (Oliva et al. 2014). Some plants may become more susceptible to initial infection during periods of environmental stress, such as drought, and, thus, facilitate an increase in spread rates of invasive pathogens. Alternatively, plants may become more likely to be damaged by previously established pathogens or by unremarkable, but possibly nonnative, endophytic microbes (Stergiopoulos and Gordon 2014). Our superficial understanding of existing microbial communities in wild plants and in wildland ecosystems is a significant barrier to our ability to predict the emergence of diseases, because many widespread invasive pathogens will be detected only after a plant health problem emerges. Thus, climate change, through its influence on host physiology (McDowell et al. 2011), is likely to divulge the presence of potentially damaging, invasive, microbial pathogens which are widespread within populations, but only after eradication is no longer feasible (Filipe et al. 2012).

Our success in managing disease-causing organisms will depend on our ability to predict their occurrence under changing climate conditions and to attack vulnerable points in the disease cycle (i.e., weak links in the infection chain). Thorough understanding of the disease cycle, including the climatic and other environmental factors that influence the cycle, is essential to effective management.

\subsubsection{Key Findings}

All aspects of climate change have the potential to directly and indirectly affect invasive species in important ways. Direct effects vary depending on the climate change component and species involved. For example, elevated $\mathrm{CO}_{2}$ can have a dramatic, positive effect on growth of invasive plants but little or no direct effect on invasive insects or pathogens, which are more affected by changes in temperature and precipitation. Indirect effects of climate change on invasive species can be equally important and occur through changes in interactions with, and/or status of, competitors and hosts. The landscape to global occurrence and distribution of invasive species can also be altered by climate change.

\subsubsection{Key Information Needs}

Most studies have examined the impacts of climate change on invasive species occurring in isolation or in simplified systems; in order to better understand impacts, more realistic studies need to be conducted in natural settings and over larger landscapes. Similarly, most studies have examined impacts of only one component of climate change on invasive species (e.g., drought or elevated $\mathrm{CO}_{2}$ but not both), even though multiple climate variables are changing simultaneously. Consequently, studies should examine the combined effects of variables on invasive species. In order to manage biological communities that are more resistant to invasions, managers need a practical understanding of how 
these climate variables influence invasive plants, insects, and pathogens.

\subsection{Ecosystem Responses to Climate Change That Affect Invasive Species}

The distribution and abundance of a species are governed by natality, growth, mortality, and dispersal of individuals comprising a population. These variables are influenced by environmental factors such as climate, among others, as mediated through fluctuations in resource availability, fecundity, fitness, and survivorship. The direct effects of climate change on invasive taxa are discussed above. Here we focus on the indirect effects as mediated through changes in habitat, hosts, disturbance, trophic interactions, and land management.

\subsubsection{Habitat and Host Range}

Climate is a primary factor regulating the geographic distributions of plants. For example, the current distribution of coniferous vegetation across Western North America resulted from climatic shifts dating back millions of years (Brunsfeld et al. 2001), along with more recent recolonization of deglaciated lands (Godbout et al. 2008). Plants tend to be adapted to a range of climatic conditions (niches), and climate change may cause shifts in the geographic distribution of these niches (Parmesan 2006) with broad implications for other species (e.g., invasive herbivores) that rely on these plants for food and/or shelter. Substantial shifts in the geographic distributions of bioclimatic envelopes (climatic niches) have been projected for grass species, shrub species, tree species, and entire communities in North America (e.g., Bradley 2009; McKenney et al. 2007; Rehfeldt et al. 2012; Wang et al. 2012). To the extent that dispersal and resource availability allow, these species and communities are expected to track associated shifts in bioclimatic envelopes over time (Pearson and Dawson 2003). For example, Parmesan and Yohe (2003) conducted a meta-analysis indicating that climate change caused an average boundary shift of $6.1 \mathrm{~km}$ per decade northward (or $6.1 \mathrm{~m}$ in elevation upward) for 99 species of birds, plants, and insects. However, climate-induced downhill shifts of plant communities can also occur (Crimmins et al. 2011), thus illustrating the diversity and complexity of plant responses to climate change. In general, shifts are expected to be most noticeable along present-day ecotones, but the fate of any individual, species, or community will depend on genetic variation, phenotypic variation, fecundity, and dispersal mechanisms. Furthermore, the resilience of plants to a multitude of stressors may be affected by climate change (Fettig et al. 2013).

\subsubsection{Host Physiology and Phenology}

For the 1000 years prior to the Industrial Revolution, concentrations of atmospheric $\mathrm{CO}_{2}$ remained stable at $\sim 270 \mathrm{ppm}$. Atmospheric $\mathrm{CO}_{2}$ is 407 ppm (December 2017, www.esrl. noaa.gov) and is projected to reach $550 \mathrm{ppm}$ by the middle of this century and to surpass $700 \mathrm{ppm}$ by the end of the century (IPCC 2007). While elevated $\mathrm{CO}_{2}$ has the potential to affect many metabolic processes in terrestrial plants with $\mathrm{C} 3$ photosynthetic pathways, impacts on Rubisco (the enzyme by which atmospheric $\mathrm{CO}_{2}$ is converted to energy in plants) and stomatal movement have been consistently demonstrated to occur within the range of $\mathrm{CO}_{2}$ concentrations associated with climate change (Long et al. 2004). Elevated $\mathrm{CO}_{2}$ increases net photosynthesis and decreases transpiration through reduced stomatal conductance and increased water-use efficiency (Wand et al. 1999), thus influencing plant growth and competition.

Smith et al. (2000) studied the effects of $\mathrm{CO}_{2}$ enrichment on growth in creosote bush (Larrea tridentata) and two deciduous shrub species in Nevada. Significant increases in shoot production were observed with a $50 \%$ increase in atmospheric $\mathrm{CO}_{2}$ in a high rainfall year but not during a low rainfall year. Similar results were observed for several annual plants including red brome (Bromus spp.), a nonnative annual grass that has invaded portions of the Southwestern United States (Hunter 1991). The density of red brome increased as a result of $\mathrm{CO}_{2}$ enrichment (Smith et al. 2000), demonstrating that increased atmospheric $\mathrm{CO}_{2}$ can influence an invasive plant through modification of its physiology and competitive interactions. Similarly, the growth of cheatgrass, a notable invasive grass in the Western United States, is also enhanced by elevated $\mathrm{CO}_{2}$ (Smith et al. 1987; Ziska et al. 2005) and increased temperature (Zelikova et al. 2013), specifically during periods of high soil moisture. While desert plants are likely to be among the most responsive to elevated $\mathrm{CO}_{2}$ (i.e., due to increases in water-use efficiency), similar relationships have been observed in many plant species. In general, elevated $\mathrm{CO}_{2}$ results in increased plant growth manifested as increased leaf area, increased leaf thickness, and larger shoots, stems, and branches (Pritchard et al. 1999).

Drought affects many components of plant nutritional quality and morphology of importance to invasive species. Most research has focused on indirect effects of drought on folivores as mediated through changes in host quality, primarily leaf chemistry, and palatability (Kolb et al. 2016). Drought often increases plant tissue concentrations of nitrogen compounds such as amino acids and nitrate, osmolytes such as sugars and inorganic ions, and allelochemicals such as cyanogenic glycosides, terpenoids, and alkaloids. These compounds were observed to increase in tissue concentration during periods of mild or moderate drought, when water stress constrains growth more than photosynthesis and root 
uptake of nutrients, and decrease during periods of long and severe drought, when intense water stress constrains growth, photosynthesis, and root uptake (Kolb et al. 2016). In particular, increases in the concentration of nitrogen compounds may affect performance of insect folivores, as nitrogen is often a limiting factor in their growth (Mattson 1980). For example, Rouault et al. (2006) commented that some defoliating insects benefited from increased nitrogen in plant tissues associated with moderate water stress during the drought and heat waves that occurred in Europe in 2003. Drought also affects certain morphological characteristics of plants, causing a decrease in leaf toughness and an increase in dry matter content, which typically reduces folivore feeding as leaf water content decreases. Interestingly, drought-stressed plants are consistently warmer than unstressed plants because reduced transpiration limits plant cooling, with differences as great as $15^{\circ} \mathrm{C}$ being observed (Mattson and Haack 1987). This has obvious implications to invasive insects due to the positive responses of most insect herbivores to increasing temperature (Bale et al. 2002). Overall, there is likely to be considerable variation in the magnitude and direction of responses to drought by invasive insects and pathogens, similar to that observed in other groups. Droughts are expected to accelerate the pace of invasion by some nonindigenous plants (Finch et al. 2016). For example, saltcedar (Tamarix ramosissima) is more drought-tolerant than co-occurring native species, and its capacity to invade is thought to increase with drought (Cleverly et al. 1997).

Plants and animals exhibit seasonality in the timing of life history events associated with temporal variation in habitat suitability. In particular, plants and insects are finely tuned to the seasonality of their environment, and shifts in phenology provide some of the most compelling evidence that species and ecosystems are being influenced by climate change (Cleland et al. 2007). Climate change has the capacity to cause phenological shifts that may result in asynchrony between different trophic levels. The potential consequences of phenological asynchrony have been demonstrated in several terrestrial and aquatic systems (Winder and Schindler 2004) and have been well documented in insect folivores of forest trees, where it has been demonstrated that timing of bud burst and shoot development can have marked impacts on insect growth and survival (Watt and McFarlane 2002). Such climate-induced developmental asynchrony has implications for both native and invasive species.

\subsubsection{Disturbances}

Disturbances (e.g., storms, wildfire, and herbivory) are relatively discrete events that affect the structure, composition, and function of ecosystems through alterations of the physical environment (White and Pickett 1985). Some distur- bances result in the release of large amounts of $\mathrm{CO}_{2}$, thereby further contributing to climate change. Climate change is expected to exacerbate the frequency and severity of many disturbances (Fettig et al. 2013; Westerling et al. 2006), which in turn influence the distribution, abundance, and impact of invasive species. For example, bark beetles feed on the phloem of trees and are important disturbances in conifer forests worldwide (Raffa et al. 2015). In Western North America, recent outbreaks of the native mountain pine beetle (Dendroctonus ponderosae) have been severe, long lasting, and well documented and have been linked to climate change (Bentz et al. 2010) and other factors (Fettig et al. 2007). Mountain pine beetle outbreaks increase host mortality rates and can result in subsequent replacement by other plant associations, including invasive species (Fettig et al. 2015; Fig. 4.4). Furthermore, outbreaks alter forest fuels with consequences to the frequency, severity, and intensity of wildfires (Jenkins et al. 2014).

A recent global meta-analysis of relevant literature concluded that wildfires, which are increasing due to climate change in many systems (Westerling et al. 2006), enhance the composition and performance of invasive plants, while having no effect on the composition and reducing performance of native plants (Alba et al. 2015). Additionally, responses appear to vary by habitat type. Invasive species groups respond most positively to wildfire in arid shrublands, temperate forests, and heathlands (Alba et al. 2015). Fire likely promotes invasion due to increased resource availability and nutrient inputs. Some invasive species (e.g., cheatgrass) create a feedback loop in which fire-promoted nonnative species further alter the fire regime to the detriment of native species (Brooks et al. 2004; D'Antonio and Vitousek 1992).

\subsubsection{Trophic Interactions}

Trophic interactions will undoubtedly be influenced by climate change, although little is known about these relationships. Some fungal pathogens of insects are important in regulating insect populations and are likely to be impacted by climate change. For example, Entomophaga maimaiga, which causes extensive epizootic in populations of the invasive gypsy moth (Lymantria dispar) in the Eastern United States, requires high levels of moisture for conidial production and discharge (Hajek 1999). Consequently, drought is expected to reduce this pathogen's impact on gypsy moth populations (Kolb et al. 2016). Studies indicate that climate change could alter the phenology of insect and plant pathogens, modify host resistance, and result in changes in the physiology of host-pathogen interactions (Coakley et al. 1999), likely with differential effects to invasive species. 


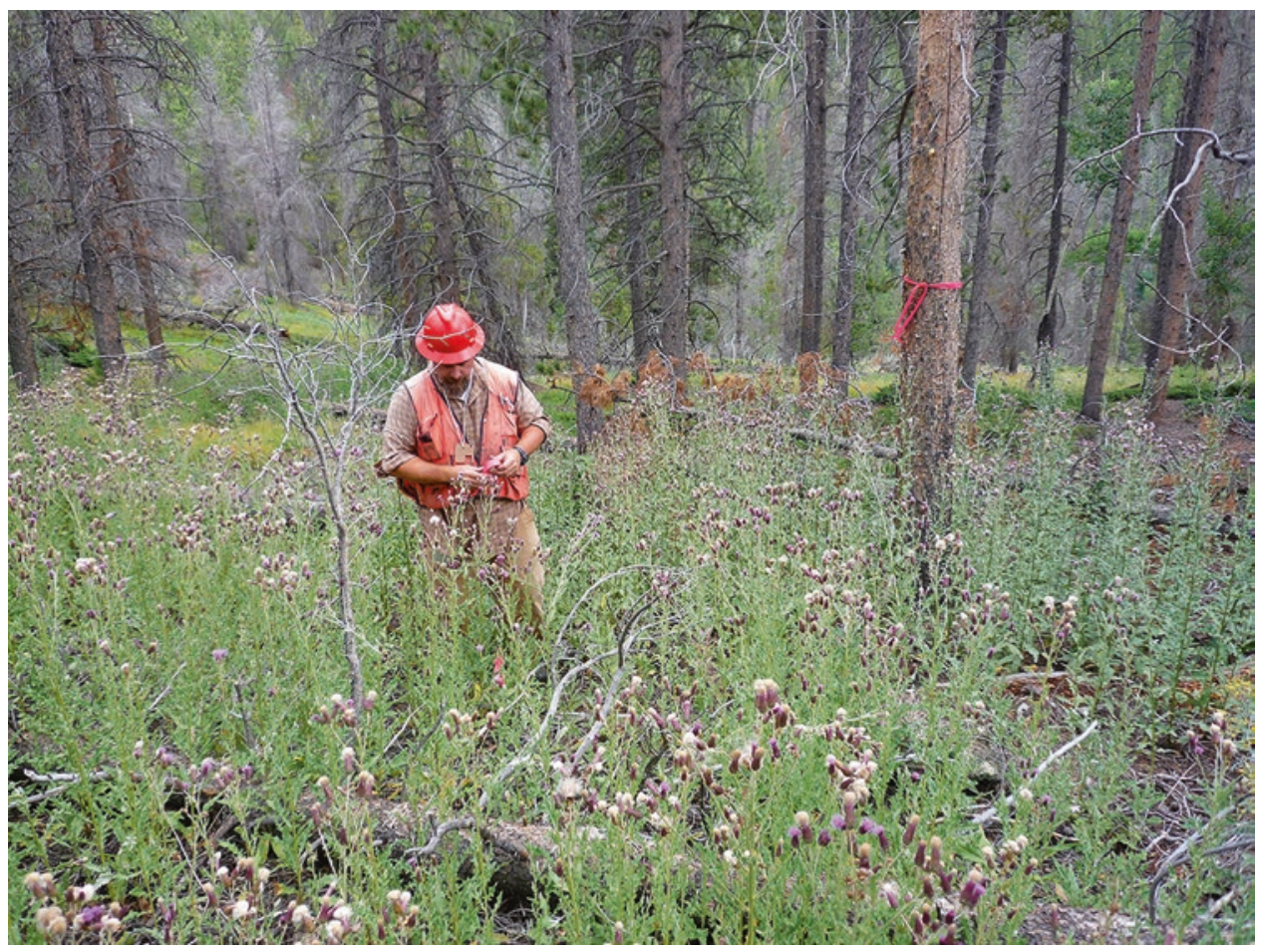

Fig. 4.4 In recent decades, billions of conifers across millions of hectares have been killed by native bark beetles in forests ranging from Alaska to Mexico, and several recent outbreaks are considered among the largest and most severe in recorded history. Temperature influences several important life history traits of bark beetles, and recent outbreaks have been linked to climate change (Bentz et al. 2010). Mountain pine beetle (Dendroctonus ponderosae) outbreaks have been particularly severe, long lasting, and well documented, with over 27 million ha impacted. One potential consequence, particularly in areas of high $(>50 \%)$ tree mortality, is subsequent invasion by nonnative plants, in this case by Canada thistle (Cirsium arvense) and bull thistle (C. vulgare) in a lodgepole pine (Pinus contorta) forest in Colorado (Fettig et al. 2015). Any activity that increases resource availability (e.g., water, nutrients, and light), increases disturbance (e.g., when trees fall), and/or decreases plant competition may promote plant invasions (Photo by Justin Runyon, USDA Forest Service)
Most species possess a large array of ecto- and endosymbiotic organisms that exhibit highly complex interactions that are often poorly understood but which may be influenced by climate change. For example, changes in temperature have been demonstrated to cause shifts in the composition of two native symbiotic (bluestain) fungi associated with conifer bark beetles (Six and Bentz 2007). Grosmannia clavigera predominates during cool periods but decreases in prevalence as daily maximum temperatures approach $25^{\circ} \mathrm{C}$, becoming extremely rare when temperatures reach or exceed $32{ }^{\circ} \mathrm{C}$. In contrast, Ophiostoma montium increases as temperatures approach $25{ }^{\circ} \mathrm{C}$ and becomes the predominant symbiont when temperatures reach or exceed $32{ }^{\circ} \mathrm{C}$ (Six and Bentz 2007). While this may be important in brood development, it is unknown if one fungus is more beneficial than the other or if effects vary by temperature. Similar relationships have been demonstrated in other systems. For example, Prado et al. (2010) showed decreases in stink bug (Acrosternum hilare and Murgantia histrionica) fitness associated with loss of gut symbionts within two generations when insects were reared at $30{ }^{\circ} \mathrm{C}$ as compared to $25^{\circ} \mathrm{C}$.

\subsubsection{Influence of Land Management on Invasive Species in a Changing Climate}

Land management to benefit native species impacted by climate change may influence shifts in the geographic distributions of invasive species through effects on their dispersal routes and mechanisms. For example, in response to climate change, managers may consider assisted migration (e.g., the practice of planting tree species outside of their current distribution due to anticipated changes in the climatic niche) (Andalo et al. 2005; Rehfeldt et al. 1999). While most efforts involving assisted migration are still experimental, largescale plantings could result in unintended introductions of other plant and animal species and/or provide new dispersal routes for established invasive species, both with unintended impacts to recipient communities.

Land management practices often influence susceptibility to disturbances exacerbated by climate change. For example, wildfires have sculpted seasonally dry forests in the Western United States for millennia. Such events reduced the quantity and continuity of forest fuels and discouraged establishment 
of fire-intolerant species. However, during the last century, fire suppression and preferential harvest of certain trees, among other factors, have increased fuels and changed forest conditions over extensive areas. As a result, wildfires tend to be larger and more severe, a trend likely to only intensify as a result of climate change (Westerling et al. 2006). Accidental introduction of invasive species, specifically plants, is frequently of concern in areas that are rehabilitated after fire (Keeley 2006). For example, following the 2000 Cerro Grande Fire in New Mexico, contamination of aerial seeding sources was responsible for inadvertently broadcasting cheatgrass seeds across recently burned areas (Keeley et al. 2006). Relatedly, prescribed fire and thinning of smalldiameter trees are used to reduce fuels in order to increase the resilience of forests to high-intensity wildfire (Stephens et al. 2012), but some studies have shown that these treatments promote an increase in invasive species richness (Schwilk et al. 2009). Climate change may also affect the efficacy of tools used to manage invasive species (Sect. 4.7).

\subsubsection{Key Findings}

The indirect effects of climate change on invasive species are primarily mediated through changes in habitats and hosts, the frequency and severity of other disturbances, trophic interactions, and land use. Climate is a primary factor regulating plants, and consequently, climate change can have an important influence on the abundance and distribution of suitable habitats and hosts and on the phenology, physiology, and morphology of hosts. In particular, plants and insects are finely tuned to the seasonality of their environment, and changes in phenology may result in asynchrony between different trophic levels affecting performance at one or more levels. Furthermore, climate change exacerbates the frequency and severity of many disturbances (e.g., wildfire), which affects the distribution, spread, abundance, and impact of invasive species. Trophic interactions will undoubtedly be influenced by climate change, although little is known about these relationships. Changes in land-use patterns and management practices in response to climate change may alter susceptibility to invasions in a variety of ways, but primarily through alterations of dispersal routes and mechanisms and accidental transport. For example, accidental introduction of invasive plants is a major concern in forests and grasslands being rehabilitated after wildfire.

\subsubsection{Key Information Needs}

Bioclimatic models being used to project changes in the distribution of invasive species, hosts, habitats, and communities would be more helpful if they were further refined and downscaled. Further studies on the effects of elevated $\mathrm{CO}_{2}$ on plant growth and invasiveness are fundamental to our understanding of how plants respond to climate change. More information is needed on the response of invasive species to other disturbances exacerbated by climate change. There is a critical need to develop adaptation strategies to manage native and invasive species (and their many interactions) effectively in the face of climate change.

\subsection{Influence of Invasive Species on Climate Change and Carbon Sequestration}

Insect and disease outbreaks can have substantial impacts on ecosystem-level carbon cycling and storage (Cobb et al. 2012a; Morehouse et al. 2008; Nuckolls et al. 2009). The consequences to carbon storage of outbreaks of invasive insects and pathogens are poorly understood as compared to other disturbances such as forest harvesting or wildfire (Nave et al. 2010, 2011). However, it is becoming increasingly clear that these events can alter forest-level carbon (C) storage. A better understanding of outbreaks will improve the understanding of such threats to the important atmospheric greenhouse gas (GHG) sink associated with forests (Hicke et al. 2012). Invasive insects and pathogens can alter the process of $\mathrm{CO}_{2}$ sequestration as biomass by reducing tree growth, killing trees, and altering the distribution of carbon within forests (Albani et al. 2010; Cobb et al. 2013; Kurz et al. 2008a). Increases in dead woody biomass (fuels or coarse woody debris) are commonly associated with outbreaks (Cobb et al. 2012a; Hoffman et al. 2012; Valachovic et al. 2011). Although dead wood is an important component of forest-level carbon storage (Harmon 2009), these increases can also lead to changes in fire behavior or impacts in complex ways (Buma 2015; Jenkins et al. 2014; Meigs et al. 2016; Metz et al. 2011; Simard et al. 2010).

Carbon storage in trees is an important component of local and regional policy aimed at capping or ameliorating GHG emissions. The potential for episodes of tree mortality to interfere seriously with these goals has been recognized for over a decade (Breshears and Allen 2002), but there has been less effort expended to predict these impacts and address them in formal forest management policies (Hicke et al. 2012; Kurz et al. 2008b). Furthermore, in terms of GHGs, forests are not solely $\mathrm{CO}_{2}$ sinks or sources. Soil microbial communities also emit methane $\left(\mathrm{CH}_{4}\right)$ and $\mathrm{N}_{2} \mathrm{O}$, gases, which have far higher radiative heating capacity on a per molecule basis than $\mathrm{CO}_{2}$ (Smeets et al. 2009). Ecosystem studies have focused mainly on $\mathrm{CO}_{2}$ because it is the major component of GHG sources within forest ecosystems, and, compared to $\mathrm{CH}_{4}$ and $\mathrm{N}_{2} \mathrm{O}$, changes in $\mathrm{CO}_{2}$ storage and exchange are better understood. In general, ecosystem $\mathrm{C}$ 
storage in the living plant biomass pool is second only to the soil C pool (Domke et al. 2018). Although plant biomass is a heterogeneous collection of compounds with different decomposition rates, those constituent compounds are relatively short-lived compared to many of the organic compounds, such as humic and fulvic acids, that form soil organic matter (Harmon 2009; Lewis et al. 2014). Reasonable estimates of changes in $\mathrm{C}$ storage during invasive pest outbreaks can be made when tree biomass can be mapped accurately, tree mortality rates and spatial patterns are known, and decomposition rates of woody debris can be measured or estimated from reliable data (Albani et al. 2010; Hicke et al. 2012; Kurz et al. 2008a).

Many invasive insects and pathogens are likely to influence ecosystem $\mathrm{C}$ storage by reducing growth and killing trees; consequently, explosive episodes of population increases and spread of these organisms are certain to have significant net impacts on this important ecosystem resource. Knowledge gained from evaluating impacts of invasive and analogous native insects and pathogens at the ecosystem level suggests that several broad categories of outbreaks will have different impacts on ecosystem C cycling (Table 4.1). The most subtle changes are likely to occur due to organisms that reduce growth rather than those that kill individual trees (Eviner and Likens 2008). Changes in C cycling can be expected to intensify depending on the interplay between stand composition and invasive insect or pathogen host range. As the range of hosts killed by these invasive organisms increases, the rate of infection/attack and the prevalence of hosts affected at stand or landscape scales will also increase, thus intensifying changes in $\mathrm{C}$ cycling. For example, the invasive hemlock woolly adelgid (HWA) alters litter decomposition, litterfall, and soil respiration rates in ways that reduce $\mathrm{C}$ storage at the stand level (Cobb 2010; Finzi et al. 2014; Orwig et al. 2013). HWA attacks on eastern hemlock (Tsuga canadensis) and Carolina hemlock (T. caroliniana) in the Eastern United States have altered $\mathrm{C}$ cycling by reducing $\mathrm{C}$ storage, a process that escalates with the amount of preoutbreak C stored in at-risk forests (Albani et al. 2010). Phytophthora ramorum, the invasive species that causes sudden oak death, is a broad-host-range pathogen that decreases litterfall and aboveground biomass (Cobb et al. 2012b, 2013); in contrast to the HWA, $P$. ramorum has differential spread and impacts among host species and causes different amounts of mortality across forest types (Metz et al. 2012).

Integrating the influence of climate change on both invasive insects and pathogens, as well as on their hosts, is critical to understanding and predicting when and how much $\mathrm{C}$ will be lost during an outbreak (Alexander 2010; Sturrock et al. 2011). Because spread rates of microbes are difficult to measure directly, proxy measurements such as repeated aerial surveys (of tree mortality) are often used to estimate pathogen dispersal and lags between exposure and mortality
Table 4.1 Types of insect or pathogen effects on host trees that affect carbon storage, with examples of both invasive and native species

\begin{tabular}{|c|c|c|}
\hline Type of effect & $\begin{array}{l}\text { Invasive species } \\
\text { causing effect }\end{array}$ & $\begin{array}{l}\text { Native species causing } \\
\text { effect }\end{array}$ \\
\hline \multirow[t]{3}{*}{$\begin{array}{l}\text { Growth } \\
\text { reduction }\end{array}$} & $\begin{array}{l}\text { 1. Many } \\
\text { Phytophthora species } \\
\text { such as P. nemorosa }\end{array}$ & $\begin{array}{l}\text { 1. Forest tent caterpillar } \\
\text { (Malacosoma disstria) }\end{array}$ \\
\hline & $\begin{array}{l}\text { 2. Elongate hemlock } \\
\text { scale (Fiorinia } \\
\text { externa) }\end{array}$ & $\begin{array}{l}\text { 2. Pseudomonas } \\
\text { syringae }\end{array}$ \\
\hline & $\begin{array}{l}\text { 3. Gypsy moth } \\
\text { (Lymantria dispar) }\end{array}$ & $\begin{array}{l}\text { 3. Swiss needle cast } \\
\text { (Phaeocryptopus } \\
\text { gaeumannii) }\end{array}$ \\
\hline \multirow[t]{3}{*}{$\begin{array}{l}\text { Scattered } \\
\text { individual tree } \\
\text { mortality }\end{array}$} & 1. Gypsy moth & $\begin{array}{l}\text { 1. Many heart rot fungi } \\
\text { such as Ganoderma } \\
\text { spp. }\end{array}$ \\
\hline & $\begin{array}{l}\text { 2. Asian long-horned } \\
\text { beetle (Anoplophora } \\
\text { glabripennis) }\end{array}$ & $\begin{array}{l}\text { 2. Engraver beetles (Ips } \\
\text { spp.) }\end{array}$ \\
\hline & 3. P. cactorum & \\
\hline \multirow{3}{*}{$\begin{array}{l}\text { Extensive } \\
\text { mortality of one } \\
\text { species (in } \\
\text { low-diversity } \\
\text { stands) }\end{array}$} & $\begin{array}{l}\text { 1. Hemlock woolly } \\
\text { adelgid (Adelges } \\
\text { tsugae) (Northeastern } \\
\text { United States) }\end{array}$ & $\begin{array}{l}\text { 1. Heterobasidion } \\
\text { irregulare }\end{array}$ \\
\hline & $\begin{array}{l}\text { 2. White pine blister } \\
\text { rust (Cronartium } \\
\text { ribicola) }\end{array}$ & $\begin{array}{l}\text { 2. Fusiform rust } \\
\text { (Cronartium fusiforme) }\end{array}$ \\
\hline & $\begin{array}{l}\text { 3. P. ramorum (in } \\
\text { Japanese larch (Larix } \\
\text { kaempferi) } \\
\text { plantations) }\end{array}$ & $\begin{array}{l}\text { 3. Dothistroma needle } \\
\text { blight (Dothistroma } \\
\text { septosporum) }\end{array}$ \\
\hline \multirow{3}{*}{$\begin{array}{l}\text { Extensive } \\
\text { selective } \\
\text { mortality of one } \\
\text { species (in multi- } \\
\text { species stands) }\end{array}$} & $\begin{array}{l}\text { 1. Cryphonectria } \\
\text { parasitica }\end{array}$ & $\begin{array}{l}\text { 1. Spruce budworm } \\
\text { (Choristoneura } \\
\text { occidentalis) (some } \\
\text { stand compositions) }\end{array}$ \\
\hline & 2. P. austrocedri & 2. H. occidentale \\
\hline & $\begin{array}{l}\text { 3. Emerald ash borer } \\
\text { (Agrilus planipennis) }\end{array}$ & \\
\hline \multirow{3}{*}{$\begin{array}{l}\text { Mortality of } \\
\text { many trees of } \\
\text { multiple species } \\
\text { (in diverse } \\
\text { stands) }\end{array}$} & 1. P. ramorum & $\begin{array}{l}\text { 1. Armillaria root } \\
\text { disease (Armillaria } \\
\text { spp.) }\end{array}$ \\
\hline & 2. P. cinnamomi & $\begin{array}{l}\text { 2. H. irregulare (some } \\
\text { stand compositions) }\end{array}$ \\
\hline & 3. Gypsy moth & \\
\hline
\end{tabular}

(Filipe et al. 2012; Fitzpatrick et al. 2011; Meentemeyer et al. 2011). Detailed biological understanding of emergent invasive insects and pathogens is a prerequisite to mapping their potential areas of outbreak risk (Meentemeyer et al. 2004, Orwig et al. 2012). However, invasive insects and pathogens are a diverse group of organisms with equally variable evolutionary histories and sensitivities to environmental variation. This implies that some invasive organisms will have increased impacts or greater spread under one climate change scenario but not under another. For example, greater winter minimum temperatures are likely to increase the potential range of HWA, which should exacerbate the loss of $\mathrm{C}$ storage at landscape and regional scales (Orwig et al. 2012, 2013). A reduction in snow cover, attributed to 
either an increase in the proportion of precipitation occurring as rain or lower overall precipitation, may decrease insulation and result in greater HWA overwinter mortality (Fitzpatrick et al. 2011; Orwig et al. 2012). Similarly, spread of $P$. ramorum is likely to be slowed by regional drought, thus affecting the distribution of this pathogen in California (Meentemeyer et al. 2011). However, changes in P. ramorum population levels may facilitate rapid reinvasion of areas once drought abates (Eyre et al. 2013).

\subsubsection{Key Findings}

Infestations of invasive insects, pathogens, and plants can disrupt forest carbon storage and rates of sequestration because they influence tree and plant growth, mortality, decomposition rates, and ecosystem processes. A better understanding of invasive species outbreaks will accelerate our understanding of the threats to the important atmospheric greenhouse gas $(\mathrm{GHG})$ sink that forests represent.

Generally, ecosystem C storage is greatest in the soil and belowground pools followed by the live plant biomass pool. Soil microbial communities emit $\mathrm{CH}_{4}$ and $\mathrm{N}_{2} \mathrm{O}$ gases, which have greater radiative heating capacity relative to $\mathrm{CO}_{2}$. Therefore, invasive organisms that alter ecosystem processes in the litter layer may have significant effects on atmospheric greenhouse gases. The changes in carbon storage attributed to outbreaks of invasive insects and pathogens can be reasonably estimated when biomass levels are accurately mapped, mortality rates and spatial patterns are known, and decomposition rates are measured or estimated from reliable data.

\subsubsection{Key Information Needs}

Given the inherent risks associated with managing forests under a changing environment, increased monitoring of invasive species distribution and impacts is needed in order to provide a baseline for comparing and understanding changes in their spread and behavior in the future. Improved techniques for detecting invasive species and an expansion of surveys are needed. A more thorough biological understanding of emergent invasive insects and pathogens is essential to improve our ability to project patterns of risk. Field experiments and modeling to understand invasive species effects on carbon cycles and to identify techniques to sustain or restore carbon sequestration affected by such species are needed to develop strategies to manage forest carbon sequestration given invasive insect and pathogen activity.

\subsection{Predicting, Monitoring, and Managing Invasions Under a Changing Climate}

\subsubsection{Modeling Future Scenarios to Predict Effects of Climate Change on Species Invasions}

As previously discussed, climate change will dramatically alter the rates and patterns of species invasion, and in many cases, it is expected to facilitate expansion of invasive species into areas that previously were climatically inaccessible through synergistic interactions (Walther et al. 2009). As such, an effective management approach would involve anticipating which species will spread to what locations at what times, monitoring to detect incipient invasions rapidly, and applying treatments to prevent or deter establishment. Once established, invasive species are usually extremely difficult to contain and almost impossible to eradicate.

A number of novel approaches for monitoring and modeling invasive species can facilitate our ability to predict their future spread under a range of climate change scenarios and disturbance regimes. These approaches are synergistic with ongoing broad-scale efforts to delineate the current distributions and patterns of spread of invasive species and to incorporate experimental data on the ecological and evolutionary characteristics of invasive species (Chown et al. 2014; Chuang and Peterson 2016). In addition, these approaches can be combined into a comprehensive monitoring, experimental, and modeling framework that includes the following components: (1) collection of georeferenced information on the extent, pattern, and genetic characteristics of current invasions; (2) genomic analysis of relatedness and genetic variation among invading populations; (3) assessment of functional and adaptive traits related to survival and spread into novel locations; and (4) development of models needed to predict rates and patterns of spread of each species as functions of disturbance history, landscape context, climate, biotic interactions, ecologically relevant species traits, and pathways of spread (such as human transportation networks). Specific methodologies utilized for each of these components can vary, but the conceptual approaches are broadly applicable.

Developing a comprehensive predictive framework involves obtaining reliable information about the current distribution and pattern of spread of invasive species to provide a baseline for monitoring future spread and acquiring data to develop models to predict the drivers of past spread and forecast future spread (Hulme 2006). Development of highquality datasets will require a concerted effort to collect geographic coordinates and obtain tissue samples for genetic analysis across an invasion and with sufficient sampling den- 
sity, frequency, and design optimization to obtain a representative sample with a high probability of detecting occurrence. In order to model future spread effectively, reliable information is needed about how landscape and ecological features affect spread probability. Sampling along climatic gradients to document relationships between invading populations and environmental variables such as temperature and precipitation is critical for identifying climatic drivers of spread and predicting effects of climate change on future spread (Shirk et al. 2018). In addition, biological composition, disturbances, land use, and probable invasion pathways should be identified in order to build comprehensive predictive models (Cushman 2015). While making robust data collections is ideal, alternate data sources such as herbarium or museum collections for evaluating distribution and spread (Elith and Leathwick 2009; Peterson 2003) may be available and useful.

Genomic analysis of relatedness and knowledge of the genetic variation among invading populations are important inputs to the development of robust models of spread in a changing climate. Knowing the genetic structure of invading populations is necessary in order to identify the factors that drive or inhibit their spread reliably (Cushman 2015). Genomic analysis can shed light on past spread such as founder events, vicariance, and secondary contact, as well as the degree to which these events have affected the gene pools of invading populations. Genomic analysis can also help determine evolutionary potential under changing climates, by separating out adaptive and nonadaptive processes (Keller and Taylor 2008), and by determining levels of genetic variation available for natural selection ( $\mathrm{Xu}$ et al. 2015). To develop robust models of genetic structure across an invasion, DNA samples need to be obtained from multiple individuals from as many invasive populations as possible. Current technology allows for the rapid sequencing of a large number of loci for a large number of individuals, which provides rich information on the genetic structure of invading populations and supports the development of robust models on the pattern and timing of their past spread, as well as provides support for models of future spread (Chown et al. 2014).

Traits that facilitate the spread of invasive species into, and favor their persistence in, novel environments are expected to undergo natural selection during the invasion process. This can result in evolutionary shifts that can affect predictions of future spread and may be particularly important in understanding the effects of climate change on species invasions (Hargreaves et al. 2015). Data from experimental investigations, such as controlled common garden, greenhouse and growth chamber studies of plants, and quarantine laboratory tests for invasive taxa such as vertebrates, insects, and disease-causing organisms, can be incorporated into predictive models to determine how evolutionary dynamics and climate might interact to drive future spread (Kilkenny and Galloway 2016). Trait data can also be taken from measurements of existing invading populations and can be especially useful for model parameterization if studies involve experimental treatments such as additions of $\mathrm{CO}_{2}$ or manipulations of temperature and moisture. Trait means and variance components, as well as trait $\times$ environment reaction curves, can be incorporated into a large variety of statistical and process-based predictive models.

Ultimately, construction of a comprehensive framework for prediction requires the development and application of spatially explicit models of spread, and usually, it involves incorporating species distribution models (SDM) of some type. SDMs predict the expected distribution of species based on species relationships to landscape characteristics (Elith and Leathwick 2009), and they have been used successfully to predict species invasions (Fernández and Hamilton 2015; Peterson 2003) and species range shifts under climate change (Hijmans and Graham 2006; Pearson and Dawson 2003). SDMs can vary widely in method, from statistical to process based. Research is progressing on ways to improve SDMs, including (1) developing better ways to characterize and reduce uncertainty in model predictions and to assess its impact on management decisions; (2) developing better strategies for model selection and evaluation, including integrating tools from other fields, such as machine learning (a method of data analysis that automates analytical model building); and (3) developing better procedures to address the complexities of both spatial and temporal scales (Elith and Leathwick 2009).

Increasingly, novel data types and modeling procedures are being incorporated into SDMs. For example, Kilkenny and Galloway (2016) used trait data from a large-scale reciprocal transplant study of the invasive vine Japanese honeysuckle to develop response functions (Wang et al. 2006) that modeled the relationship between juvenile winter survival and winter temperature for populations from two different regions (core and northern margin). Core and margin populations showed adaptive differentiation in their ability to survive, with margin populations having a significant survival advantage under controlled conditions in gardens planted beyond the current range edge. When the response functions were used to model spread under future climate scenarios, the survival advantage of margin populations persisted.

In another example, Cushman (2015) developed a spatially explicit spread model that combined both local spread as a function of landscape resistance and long-distance colonization through transportation networks to improve predictions of the distribution and spread of invasive species. This type of spread modeling, when combined with advanced individual-based genetic simulations (CDPOP; Landguth and Cushman 2010), landscape dynamic simulation modeling (Cushman et al. 2011), and sophisticated multimodel 
optimization of patterns of gene flow (Cushman et al. 2013), can enable researchers and managers to: (1) identify the climatic, disturbance, management, and landscape factors driving spread of different invasive species; (2) predict patterns of future spread under a range of scenarios involving altered climate, disturbance, and management regimes; and (3) utilize this information to optimize monitoring in areas predicted to be most vulnerable to future invasion, or where biocontrol will be most effective.

\subsubsection{Management and Restoration Techniques}

Lovett et al. (2016) explored a broad range of management and policy applications for managing invasive species. Critical among these was the need to strengthen defenses against pest arrival and establishment, including taking measures to inspect and ensure clean shipments of plant and wood products prior to and after shipment and implementing postentry measures such as quarantines, surveillance, and eradication programs. Improving such pre- and postentry defenses will help reduce rates of initial introductions of invasive species whose spread may be favored by climate variation.

Impacts of Climate Change on Mechanical Control Strategies Mechanical control strategies (e.g., cutting, girdling, and tilling) are useful to combat some invasive species, especially plants. The effectiveness of this technique may vary as a result of climate change. In areas where cold temperatures and hard freezes make mechanical control feasible, warmer winter temperatures may make it more expensive. If warmer winter temperatures allow these species to overwinter, greater survival rates and an increased number of generations can be expected. While fire may be helpful in controlling insects and pests, it may facilitate dominance by several fire-adapted invasive plants. For example, under hotter temperatures and reduced moisture associated with climate change, cheatgrass tends to enhance the size of wildfires and cause the wildfire season to begin earlier and continue later into the fall. Cheatgrass and other invasive species can recover faster following fires and thus suppress many native species. Consequently, more frequent fires lead to irreversible losses of native shrubs and grasses, threatening not only the habitat but the survival of species such as greater sage grouse (Centrocercus urophasianus), which is dependent on the shrub-steppe environment. These interactions complicate decision-making on how best to manage and restore infested areas.
Impacts of Climate Change on Effectiveness of Herbicides Herbicides are commonly used to manage invasive plants, and there is evidence suggesting that climate change could alter their effectiveness. For example, increases in $\mathrm{CO}_{2}$ can increase the tolerance of some weeds to the herbicide glyphosate, though the underlying mechanism is not fully understood (Ziska et al. 1999). Moreover, herbicides applied during periods of drought are generally less effective than those applied when moisture is adequate (Bussan and Dyer 1999; Kogan and Bayer 1996). For example, Morrison et al. (1995) found that drought stress reduced translocation of herbicides and thus adversely affected control of Russian knapweed (Acroptilon repens). Kogan and Bayer (1996) determined that plants responded to drought stress by reducing uptake and translocation of herbicides. When applied during high temperatures, herbicides, including the active ingredients therein, are much more likely to volatilize (Behrens and Lueschen 1979; Tabernero et al. 2000), resulting in drift to nontarget areas (Jordan et al. 2009) and inadequate control of target invasive plants. Active ingredients may also be heat labile, causing them to break down before they can be translocated. However, we still lack a good understanding of the potential impacts of climate change on the effective use of herbicides for managing invasive plants.

Impacts of Climate Change on Biological Control of Invasive Species The efficacy of certain biocontrol agents (e.g., pathogenic fungi, insect predators, and plant herbivores) may be impacted by climate change. Many studies have highlighted the importance of environmental temperature in mediating the outcome of host-pathogen and hostparasite interactions (Thomas and Blanford 2003) and are relevant to managing invasive species under a changing climate. For example, climate change can exert important direct and indirect effects on insect herbivores commonly used in managing invasive plants (Runyon et al. 2012). Increasing temperatures generally lead to shorter development times and greater survival of insect herbivores (Bale et al. 2002) and, in some species, can increase the number of generations per year (Tobin et al. 2008; Altermatt 2010). Drought can also have either a positive or negative effect on herbivores (Finch et al. 2016). Climate warming could also shift the geographic distribution of invasive plants and biocontrol agents.

There is evidence that range shifts caused by warming can increase the impact of biocontrol agents on nontarget plants (Lu et al. 2015). However, Lu et al. (2016) reported that warming can also shift plant communities from invader dominated to native dominated in the presence of a biocontrol beetle. Perhaps the most significant impact of climate change on biocontrol is through disruption in plant-herbivore syn- 
chrony. Rising temperatures could result in the herbivore being present when the targeted plant or plant stage is absent; this can occur because temperature and photoperiod can have a variable effect on the development of plant and herbivore species (Bale et al. 2002). Although there are no reported cases of such asynchrony in weed biocontrol, there are examples of climate-induced asynchrony occurring in some plant/herbivore species (van Asch et al. 2007); therefore, biocontrol practitioners should be aware of this potential response to climate change.

Climate change can also indirectly affect biocontrol by altering the basic nutritional value of plants. For example, elevated $\mathrm{CO}_{2}$ increases plant growth (the "fertilizer effect") and the ratio of carbon-to-nitrogen $(\mathrm{C}: \mathrm{N})$ in plant tissues, which reduces the nutritional quality for nitrogen-limited insects (Coviella and Trumble 1999). This causes insects to consume more foliage to compensate for reduced nitrogen content (Coviella and Trumble 1999; Dermody et al. 2008; Johnson and $\mathrm{McNicol} 2010$ ). Elevated $\mathrm{CO}_{2}$ can also increase leaf sugar content of plants and spur herbivores to consume more foliage from plants growing under high $\mathrm{CO}_{2}$ conditions (Hamilton et al. 2005). These findings suggest that elevated $\mathrm{CO}_{2}$ could enhance biocontrol if it induces herbivores to increase the rate and volume or biomass of invasive plants consumed. Climate change may also affect plant nutritional value by altering chemical defenses against herbivores. Climatic factors including drought, elevated $\mathrm{CO}_{2}$, temperature, ozone $\left(\mathrm{O}_{3}\right)$, and UV light, singly and in combination, can affect levels of plant secondary chemicals (Bidart-Bouzat and Imeh-Nathaniel 2008; Huberty and Denno 2004; Percy et al. 2002; Yuan et al. 2009). Interestingly, flavonoid and cyanide concentrations decreased in foliage of invasive garlic mustard (Alliaria petiolata) growing under elevated $\mathrm{CO}_{2}$ and temperatures (Anderson and Cipollini 2013), which could enhance the efficacy of biocontrol agents. However, we have a poor understanding of how climate-induced changes influence secondary plant chemistry, and available knowledge indicates that the response is dependent on the plant and insect species involved and the class of chemicals examined (Bidart-Bouzat and Imeh-Nathaniel 2008). A better understanding of how climate change will impact the interactions between invasive organisms and their biocontrol agents is needed.

Impacts of Climate Change on Restoration Strategies Climate change may alter the success of restoration strategies used to combat invasive species and may also affect the utility of restoring natural disturbance regimes as a strategy to control invasive species (Hellmann et al. 2008). Revegetation is often necessary following the control of invasive plant species in natural environments; otherwise, the empty niche may be occupied by other undesirable species (Pearson et al. 2016). The success of such revegetation attempts can be hindered by extreme weather events such as frequent floods and droughts. As mentioned previously, prescribed fire can be used either alone or when combined with other control tactics as a strategy to control several invasive species, including plants, insects, and pathogens. However, altered fire regimes that are associated with climate change can adversely affect the use of prescribed fire as a restoration tool.

\subsubsection{Key Findings}

A number of novel monitoring and modeling approaches can be used to facilitate prediction of the future spread of invasive species under a range of climate change scenarios and disturbance regimes. Effective modeling of future spread requires acquiring reliable information not only about how landscape and ecological features affect spread probability but also how climatic gradients influence invading populations and their interactions with other environmental variables. Genomic analysis can shed light on past spread such as founder events, vicariance, and secondary contact, as well as the degree to which these events have affected the gene pools of invading populations.

Mechanical control strategies and herbicides are commonly used to combat some invasive species, but their effectiveness and cost may change as a result of climate change. Climate change and drought can also exert important direct and indirect effects on insect herbivores used to manage invasive plants. Increasing temperatures generally result in shorter development times and greater survival of insect herbivores and can increase the number of generations per year in some species. Warming climates could conceivably improve effectiveness of insect biocontrol agents applied in invaded areas, provided the ranges of host and biocontrol insects are matched rather than altered by climate change and plant chemical defenses are not intensified. Success of restoration strategies, such as those involving revegetation and prescribed fire, can be impacted by climate change.

\subsubsection{Key Information Needs}

Sampling along climatic gradients is needed to document relationships between invading populations and environmental variables, such as temperature and precipitation, and is critical for identifying climatic drivers of spread and predicting effects of climate change on future spread. Also needed are better range models for predicting invasive species occurrence that incorporate dispersal and demographic processes. Genomic analysis of relatedness and genetic variation among invading populations is also needed to develop robust models of spread under a changing climate. Knowledge of the 
genetic structure of invading populations is required to reliably identify how climate change can drive or inhibit their spread. With respect to methods for controlling invasive species, we still lack a good understanding of the potential impacts of climate change on the effective use of herbicides or mechanical methods utilized to manage invasive plants. We need a better understanding of how climate change will impact the interactions among invasive organisms and their biocontrol agents, as well as the effectiveness of biocontrol agents. Finally, new knowledge is needed on improving success of restoration strategies under varying climates following control and/or removal of invasive species.

Acknowledgments We thank David Hawksworth for assistance in eliminating duplicate references and integrating them and Yancey Ranspot for help in adjusting format. We thank Sharlene Sing, Matt Ayres, Eric Holzmueller, and Chris Weber for their manuscript reviews. We also thank the editors for their instrumental work on the volume.

Disclaimer Text The findings and conclusions in this publication are those of the authors and should not be construed to represent any official USDA or U.S. Government determination or policy.

\section{Literature Cited}

Adams HD, Guardiola-Claramonte M, Barron-Gafford GA et al (2009) Temperature sensitivity of drought-induced tree mortality portends increased regional die-off under global-change-type drought. Proc Natl Acad Sci 106:7063-7066

Alba C, Skálová H, McGregor KF et al (2015) Native and exotic plant species respond differently to wildfire and prescribed fire as revealed by meta-analysis. J Veg Sci 26:102-113

Albani M, Moorcroft PR, Ellison AM et al (2010) Predicting the impact of hemlock woolly adelgid on carbon dynamics of eastern United States forests. Can J For Res 40:119-133

Alexander HM (2010) Disease in natural plant populations, communities, and ecosystems: insights into ecological and evolutionary processes. Plant Dis 94:492-503

Alexander JM, Edwards PJ, Poll M et al (2009) Establishment of parallel altitudinal clines in traits of native and introduced forbs. Ecology 90:612-622

Altermatt F (2010) Climatic warming increases voltinism in European butterflies and moths. Proc R Soc Lond B Biol Sci 277:1281-1287

Anagnostakis SL (1982) Biological control of chestnut blight. Science 215:466-471

Andalo C, Beaulieu J, Bousquet J (2005) The impact of climate change on growth of local white spruce populations in Quebec. Canada Forest Ecol Manag 205:169-182

Anderegg WRL, Berry JA, Smith DD et al (2012) The roles of hydraulic and carbon stress in a widespread climate-induced forest die-off. Proc Natl Acad Sci 109:233-237

Anderson LJ, Cipollini D (2013) Gas exchange, growth, and defense responses of invasive Alliaria petiolata (Brassicaceae) and native Geum vernum (Rosaceae) to elevated atmospheric $\mathrm{CO}_{2}$ and warm spring temperatures. Am J Bot 100:1544-1554

Archer SR, Predick KI (2008) Climate change and ecosystems of the southwestern United States. Rangelands 30:23-28

Bale JS, Hayward SAL (2010) Insect overwintering in a changing climate. J Exp Biol 213:980-994
Bale JS, Masters GJ, Hodkinson ID et al (2002) Herbivory in global change research: direct effects of rising temperature on insect herbivores. Glob Chang Biol 8:1-16

Barbier EB, Gwaitpedza J, Knowlder D et al (2011) The North American horticultural industry and the risk of plant invasion. Agric Econ 42:113-129

Barrett SCH (2000) Microevolutionary influences of global changes on plant invasions. In: Mooney HA, Hobbs RJ (eds) Invasive species in a changing world. Island Press, Washington, DC, pp 115-139

Beaumont LJ, Gallagher RV, Thuiller W et al (2009) Different climatic envelopes among invasive populations may lead to underestimations of current and future biological invasions. Divers Distrib 15:409-420

Behrens R, Lueschen WE (1979) Dicamba volatility. Weed Sci 27:486-493

Bellard C, Thuiller W, Leroy B et al (2013) Will climate change promote future invasions? Glob Chang Biol 19:3740-3748

Belote RT, Weltzin JF, Norby RJ (2003) Response of an understory plant community to elevated $\left[\mathrm{CO}_{2}\right]$ depends on differential responses of dominant invasive species and is mediated by soil water availability. New Phytol 161:827-835

Bentz BJ, Régnière J, Fettig CJ et al (2010) Climate change and bark beetles of the western United States and Canada: direct and indirect effects. Bioscience 60:602-613

Bernard-Verdier M, Hulme PE (2015) Alien and native plant species play different roles in plant community structure. J Ecol 103:143-145

Bidart-Bouzat MG, Imeh-Nathaniel A (2008) Global change effects on plant chemical defenses against insect herbivores. J Integr Plant Biol 50:1339-1354

Blossey B, Nötzold R (1995) Evolution of increased competitive ability in invasive nonindigenous plants: a hypothesis. J Ecol 83:887-889

Blumenthal DM, Kray JA (2014) Climate change, plant traits and invasion in natural and agricultural ecosystems. In: Ziska LH, Dukes JS (eds) Invasive species and global climate change. CAB International, Oxfordshire, pp 62-78

Blumenthal D, Chimner RA, Welker JM, Morgan JA (2008) Increased snow facilitates plant invasion in mixedgrass prairie. New Phytol 179:440-448

Blumenthal DM, Resco V, Morgan JA et al (2013) Invasive forb benefits from water savings by native plants and carbon fertilization under elevated $\mathrm{CO}_{2}$ and warming. New Phytol 200:1156-1165

Bostock RM, Pye MF, Roubtsova TV (2014) Predisposition in plant disease: exploiting the nexus in abiotic and biotic stress perception and response. Annu Rev. Phytopathol 52:517-549

Bradley BA (2009) Regional analysis of the impacts of climate change on cheatgrass invasion shows potential risk and opportunity. Glob Chang Biol 15:196-208

Bradley BA (2014) The biogeography of invasive plants - projecting range shifts with climate change. In: Ziska LH, Dukes JS (eds) Invasive species and global climate change. $\mathrm{CAB}$ International, Oxfordshire, pp 240-252

Bradley BA, Wilcove DS (2009) When invasive plants disappear: transformative restoration possibilities in the Western United States resulting from climate change. Restor Ecol 17:715-721

Bradley BA, Blumenthal DM, Wilcove DS, Ziska LH (2010) Predicting plant invasions in an era of global change. Trends Ecol Evol 25:310-318

Bradley BA, Bluementhal DM, Early R et al (2012) Global change, global trade, and the next wave of plant invasions. Front Ecol Environ 10:20-28

Bradley BA, Early R, Sorte CJB (2015) Space to invade? Comparative range infilling and potential range of invasive and native plants. Glob Ecol Biogeogr 24:348-359

Brasier CM (2008) The biosecurity threat to the UK and global environment from international trade in plants. Plant Pathol 57:792-808 
Brasier CM, Webber J (2010) Plant pathology: sudden larch death. Nature 466:824-825

Breshears DD, Allen CD (2002) The importance of rapid, disturbanceinduced losses in carbon management and sequestration. Glob Ecol Biogeogr 11:1-5

Broennimann O, Guisan A (2008) Predicting current and future biological invasions: both native and invaded ranges matter. Biol Lett 4:585-589

Broennimann O, Treier UA, Müller-Schärer H et al (2007) Evidence of climatic shifts during biological invasion. Ecol Lett 10:701-709

Brooks ML, D'Antonio CM, Richardson DM et al (2004) Effects of invasive alien plants on fire regimes. Bioscience 54:677-688

Brunsfeld SJ, Sullivan J, Soltis DE, Soltis PS (2001) Comparative phylogeography of northwestern North America: A synthesis. In: Silvertown J, Antonovics J (eds) Integrating ecology and evolution in a spatial context. Blackwell Science, Oxford, pp 319-339

Buma B (2015) Disturbance interactions: characterization, prediction, and the potential for cascading effects. Ecosphere 6:70

Burkle LA, Runyon JB (2016) Drought and leaf herbivory influence floral volatiles and pollinator attraction. Glob Chang Biol 22:1644-1654

Bussan AJ, Dyer WE (1999) Herbicides and rangeland. In: Sheley R, Petroff J (eds) Biology and management of noxious rangeland weeds. Oregon State University Press, Corvallis, pp 116-132

Cannon RJ (1998) The implications of predicted climate change for insect pests in the UK, with emphasis on non-indigenous species. Glob Chang Biol 4:785-796

Carroll SP, Hendry AP, Reznick DN, Fox CW (2007) Evolution on ecological time-scales. Funct Ecol 21:387-393

Chown SL, Hodgins KA, Griffin PC, Oakeshott JG, Byrne M, Hoffmann AA (2014) Biological invasions, climate change and genomics. Evol Appl 8:23-46

Chuang A, Peterson CR (2016) Expanding population edges: theories, traits, and trade-offs. Glob Chang Biol 22:494-512

Cleland EE, Chuine I, Menzel A et al (2007) Shifting plant phenology in response to global change. Trends Ecol Evol 22:357-365

Cleverly JR, Smith SD, Sala A, Devitt DA (1997) Invasive capacity of Tamarix ramosissima in a Mojave Desert floodplain: the role of drought. Oecologia 111:12-18

Coakley SM, Scherm H, Chakraborty S (1999) Climate change and plant disease management. Annu Rev. Phytopathol 37:399-426

Cobb RC (2010) Species shift drives decomposition rates following invasion by hemlock woolly adelgid. Oikos 119:1291-1298

Cobb RC, Chan MN, Meentemeyer RK, Rizzo DM (2012a) Common factors drive disease and coarse woody debris dynamics in forests impacted by sudden oak death. Ecosystems 15:242-255

Cobb RC, Filipe JAN, Meentemeyer RK, Gilligan CA, Rizzo DM (2012b) Ecosystem transformation by emerging infectious disease: loss of large tanoak from California forests. J Ecol 100:712-722

Cobb RC, Eviner VT, Rizzo DM (2013) Mortality and community changes drive sudden oak death impacts on litterfall and soil nitrogen cycling. New Phytol 200:422-431

Colautti RI, Barrett SCH (2013) Rapid adaptation to climate facilitates range expansion of an invasive plant. Science 342:364-366

Corlett RT, Westcott DA (2013) Will plant movements keep up with climate change? Trends Ecol Evol 28:482-488

Corn JG, Story JM, White LJ (2006) Impacts of the biological control agent Cyphocleonus achates on spotted knapweed, Centaurea maculosa, in experimental plots. Biol Control 37:75-81

Coughlan NE, Kelly TC, Jansen MAK (2015) Mallard duck (Anas platyrhynchos)-mediated dispersal of Lemnacae: a contributing factor in the spread of the invasive Lemna minuta? Plant Biol 17:108-114

Coviella CE, Trumble JT (1999) Effects of elevated atmospheric carbon dioxide on insect-plant interactions. Conserv Biol 13:700-712
Crawford KM, Whitney KD (2010) Population genetic diversity influences colonization success. Mol Ecol 19:1253-1263

Crimmins SM, Dobrowski SZ, Greenberg JA et al (2011) Changes in climatic water balance drive downhill shifts in plant species' optimum elevations. Science 331:324-327

Cushman SA (2015) Pushing the envelope in genetic analysis of species invasion. Mol Ecol 24:259-262

Cushman SA, Wasserman TN, McGarigal K (2011) Modeling landscape fire and wildlife habitat. In: McKenzie D, Miller C, Falk DA (eds) The landscape ecology of fire. Ecological studies (analysis and synthesis). Springer, Dordrecht, pp 223-245

Cushman SA, Wasserman TN, Landguth EL, Shirk AJ (2013) Re-evaluating causal modeling with Mantel tests in landscape genetics. Diversity 5:51-72

D’Antonio CM, Vitousek PM (1992) Biological invasions by exotic grasses, the grass/fire cycle, and global change. Annu Rev. Ecol Syst 23:63-87

Davidson JM, Patterson HA, Rizzo DM (2008) Sources of inoculum for Phytophthora ramorum in a redwood forest. Phytopathology 98:860-866

Dermody O, O'Neill BF, Zangerl AR et al (2008) Effects of elevated $\mathrm{CO}_{2}$ and $\mathrm{O}_{3}$ on leaf damage and insect abundance in a soybean agroecosystem. Arthropod Plant Interact 2:125-135

Desprez-Loustau ML, Marçais B, Nageleisen LM et al (2006) Interactive effects of drought and pathogens in forest trees. Ann For Sci 63:597-612

Deutsch CA, Tewksbury JJ, Huey RB et al (2008) Impacts of climate warming on terrestrial ectotherms across latitude. Proc Natl Acad Sci 105:6668-6672

Diez JM, D'Antonio CM, Dukes JS et al (2012) Will extreme climatic events facilitate biological invasions? Front Ecol Environ 10:249-257

Domke G, Williams CA, Birdsey R et al (2018) Chap. 9: Forests. In: Cavallaro N, Shrestha G, Birdsey R, Mayes MA, Najjar RG et al (eds) Second state of the carbon cycle report (SOCCR2): a sustained assessment report. Washington, DC: U.S. Global Change Research Program. Pages: 365-398

Dostál P, Müllerová J, Pyšek P et al (2013) The impact of an invasive plant changes over time. Ecol Lett 16:1277-1284

Dukes JS (2000) Will the increasing atmospheric $\mathrm{CO}_{2}$ concentration affect the success of invasive species? In: Mooney HA, Hobbs RJ (eds) Invasive species in a changing world. Island Press, Washington, DC, pp 95-113

Dukes JS (2011) Responses of invasive species to a changing climate and atmosphere. In: Richardson DM (ed) Fifty years of invasion ecology: the legacy of Charles Elton. Oxford, UK, Wiley-Blackwell, pp 345-357

Dukes JS, Mooney HA (1999) Does global change increase the success of biological invaders? Trends Ecol Evol 14:135-139

Dukes JS, Pontius J, Orwig D et al (2009) Responses of insect pests, pathogens, and invasive plant species to climate change in the forests of northeastern North America: what can we predict? Can J For Res 39:231-248

Dukes JS, Chiariello NR, Loarie SR, Field CB (2011) Strong response of an invasive plant species (Centaurea solstitialis L.) to global environmental changes. Ecol Appl 21:1887-1894

Dunson WA, Travis J (1991) The role of abiotic factors in community organization. Am Nat 138:1067-1091

Early R, Sax DF (2014) Climatic niche shifts between species' native and naturalized range raise concern for ecological forecasts during invasion and climate change. Glob Ecol Biogeogr 23:1356-1365

Elith J, Leathwick JR (2009) Species distribution models: ecological explanation and prediction across time and space. Annu Rev. Ecol Evol Syst 40:677-697

Eviner VT, Likens GE (2008) Effects of pathogens on terrestrial ecosystem function. In: Ostfeld RS, Keesing F, Eviner VT (eds) Infectious 
disease ecology. Effects of ecosystems on disease and disease on ecosystems. Princeton University Press, Princeton, pp 260-283

Eyre CA, Kozanitas M, Garbelotto M (2013) Population dynamics of aerial and terrestrial populations of Phytophthora ramorum in a California forest under different climatic conditions. Phytopathology 103:1141-1152

Fernández M, Hamilton H (2015) Ecological niche transferability using invasive species as a case study. PLoS One 10:e0119891

Fettig CJ, Klepzig KD, Billings RF et al (2007) The effectiveness of vegetation management practices for prevention and control of bark beetle infestations in coniferous forests of the western and southern United States. For Ecol Manag 238:24-53

Fettig CJ, Reid ML, Bentz BJ et al (2013) Changing climates, changing forests: a western North American perspective. J For 111:214-228

Fettig CJ, Gibson KE, Jørgensen CL et al (2015) The impacts of mountain pine beetle (Dendroctonus ponderosae) outbreaks on forest conditions in the Intermountain West. In: Potter KM, Conkling BL (eds) Forest health monitoring: national status, trends, and analysis, 2014. Forest health monitoring national technical report. U.S. Department of Agriculture, Forest Service, Southern Research Station, Asheville, pp 117-183

Filipe JAN, Cobb RC, Meentemeyer RK et al (2012) Landscape epidemiology and control of pathogens with cryptic and long-distance dispersal: sudden oak death in northern Californian forests. PLoS Comput Biol 8:e1002328

Finch DM, Pendleton RL, Reeves MC et al (2016) Rangeland drought: Effects, restoration, and adaptation [Chap. 8]. In: Vose JM, Clark JS, Luce CH, Patel-Weynand T (eds) Effects of drought on forests and rangelands in the United States: a comprehensive science synthesis. General technical report WO-93b. Washington, DC: U.S. Department of Agriculture, Forest Service, Washington Office: $155-194$

Finzi AC, Raymer PCL, Giasson M-A, Orwig DA (2014) Net primary production and soil respiration in New England hemlock forests affected by the hemlock woolly adelgid. Ecosphere 5:98

Fitzpatrick MC, Preisser EL, Porter A et al (2011) Modeling range dynamics in heterogeneous landscapes: invasion of the hemlock woolly adelgid in eastern North America. Ecol Appl 22:472-486

Gilman SE, Urban MC, Tewksbury J et al (2010) A framework for community interactions under climate change. Trends Ecol Evol 25:325-331

Godbout J, Fazekas A, Newton CH, Yeh FC (2008) Glacial vicariance in the Pacific Northwest: evidence from a lodgepole pine mitochondrial DNA minisatellite for multiple genetically distinct and widely separated refugia. Mol Ecol 17:2463-2475

Grant PR, Grant BR (2002) Unpredictable evolution in a 30-year study of Darwin's finches. Science 296:707-711

Guerenstein PG, Hildebrand JG (2008) Roles and effects of environmental carbon dioxide in insect life. Annu Rev Entomol 53:161-178

Guisan A, Petitpierre B, Broennimann O et al (2014) Unifying niche shift studies: insights from biological invasions. Trends Ecol Evol 29:260-269

Hajek AE (1999) Pathology and epizootiology of Entomophaga maimaiga infections in forest Lepidoptera. Microbiol Mol Biol Rev 63:814-835

Hamilton JG, Dermody O, Aldea M et al (2005) Anthropogenic changes in tropospheric composition increase susceptibility of soybean to insect herbivory. Environ Entomol 34:479-485

Hansen EM (2015) Phytophthora species emerging as pathogens of forest trees. Curr For Rep 1:16-24

Hargreaves AL, Bailey SF, Laird RA (2015) Fitness declines towards range limits and local adaptation to climate affect dispersal evolution during climate-induced range shifts. J Evol Biol 28:1489-1501

Harmon ME (2009) Woody detritus mass and its contribution to carbon dynamics of old-growth forests: The temporal context. In: Wirth C, Gleixner G, Heimann M (eds) Old-growth forests. Ecological stud- ies (analysis and synthesis), vol 207. Springer, Berlin/Heidelberg, pp 159-190

Hartmann H, Ziegler W, Kolle O et al (2013) Thirst beats hunger declining hydration during drought prevents carbon starvation in Norway spruce saplings. New Phytol 200:340-349

Hellmann JJ, Byers JE, Bierwagen BG, Dukes JS (2008) Five potential consequences of climate change for invasive species. Conserv Biol 22:534-543

Hicke JA, Allen CD, Desai AR et al (2012) Effects of biotic disturbances on forest carbon cycling in the United States and Canada. Glob Chang Biol 18:7-34

Hiebert RD (1997) Prioritizing invasive plants and planning for management. In: Luken JO, Thieret JW (eds) Assessment and management of plant invasion. New York: Springer-Verlag, Inc. Pages $195-212$

Higgins SI, Richardson DM (2014) Invasive plants have broader physiological niches. Proc Natl Acad Sci 111:10610-10614

Hijmans RJ, Graham CH (2006) The ability of climate envelope models to predict the effect of climate change on species distributions. Glob Chang Biol 12:2272-2281

Hoffman C, Morgan P, Mell W et al (2012) Numerical simulation of crown fire hazard immediately after bark beetle-caused mortality in lodgepole pine forests. For Sci 58:178-188

Huberty AF, Denno RF (2004) Plant water stress and its consequences for herbivorous insects: a new synthesis. Ecology 85:1383-1398

Hulme PE (2006) Beyond control: wider implications for the management of biological invasions. J Appl Ecol 43:835-847

Hulme PE (2009) Trade, transport and trouble: managing invasive species pathways in an era of globalization. J Appl Ecol 46:10-18

Hunter R (1991) Bromus invasions on the Nevada Test Site: present status of $B$. rubens and $B$. tectorum with notes on their relationship to disturbance and altitude. Great Basin Naturalist 51:176-182

Intergovernmental Panel on Climate Change (IPCC) (2007) Climate change 2007: The physical science basis. In: Solomon S, Qin D, Manning $\mathrm{M}$ et al (eds) Contribution of Working Group I to the Fourth Assessment Report of the Intergovernmental Panel on Climate Change. Cambridge University Press, Cambridge, UK/ New York. $996 \mathrm{p}$

Jamieson MA, Burkle LA, Manson JS et al (2017) Global change effects on plant-insect interactions: the role of phytochemistry. Curr Opin Insect Sci 23:70-80

Jarnevich CS, Holcombe TR, Bella EM et al (2014) Cross-scale assessment of potential habitat shifts in a rapidly changing climate. Invasive Plant Sci Manag 7:491-502

Jenkins MJ, Runyon JB, Fettig CJ et al (2014) Interactions among the mountain pine beetle, fires, and fuels. For Sci 60:489-501

Jeschke JM, Strayer DL (2008) Usefulness of bioclimatic models for studying climate change and invasive species. Ann N Y Acad Sci 1134:1-24

Johnson SN, McNicol JW (2010) Elevated $\mathrm{CO}_{2}$ and abovegroundbelowground herbivory by the clover root weevil. Oecologia 162:209-216

Jones CC (2012) Challenges in predicting the future distribution of invasive plant species. For Ecol Manag 284:69-77

Jordan T, Nice G, Johnson B, Bauman T (2009) Reducing spray drift from glyphosate and growth regulator herbicide drift caution. Purdue University Extension Weed Science. https://ag.purdue.edu/ btny/weedscience/Documents/ReducingDrift09.pdf

Keeley JE (2006) Fire management impacts on invasive plants in the western United States. Conserv Biol 20:375-384

Keeley JE, Allen CD, Betancourt J et al (2006) A 21st century perspective on postfire seeding. J For 104:1-2

Keller SR, Taylor DR (2008) History, chance and adaptation during biological invasion: separating stochastic phenotypic evolution from response to selection. Ecol Lett 11:852-866 
Keller SR, Sowell DR, Neiman M, Wolfe LM, Taylor DR (2009) Adaptation and colonization history affect the evolution of clines in two introduced species. New Phytol 183:678-690

Kilkenny FF, Galloway LF (2013) Adaptive divergence at the margin of an invaded range. Evolution 67:722-731

Kilkenny FF, Galloway LF (2016) Evolution of marginal populations of an invasive vine increases the likelihood of future spread. New Phytol 209:1773-1780

Knepp RG, Hamilton JG, Mohan JE et al (2005) Elevated $\mathrm{CO}_{2}$ reduces leaf damage by insect herbivores in a forest community. New Phytol 167:207-218

Kogan M, Bayer DE (1996) Herbicide uptake as influenced by plant water status. Pestic Biochem Physiol 56:174-182

Kolb TE, Fettig CJ, Bentz BJ et al (2016) Insects and pathogens. In: Vose J, Clark J, Luce C, Patel-Weynand T (eds) Effects of drought on forest ecosystems: a comprehensive science synthesis. WO-GTR-93b. Washington, DC: U.S. Department of Agriculture, Forest Service, Washington Office: 113-133

Kooyers NJ, Olsen KM (2012) Rapid evolution of an adaptive cyanogenesis cline in introduced North American white clover (Trifolium repens L.). Mol Ecol 21:2455-2468

Kuebbing SE, Nuñez MA, Simberloff D (2013) Current mismatch between research and conservation efforts: the need to study cooccurring invasive plant species. Biol Conserv 160:121-129

Kukla G, Karl TR (1993) Nighttime warming and the greenhouse effect. Environ Sci Technol 27:1468-1474

Kumschick S, Hufbauer RA, Alba C et al (2013) Evolution of fastgrowing and more resistant phenotypes in introduced common mullein (Verbascum thapsus). J Ecol 101:378-387

Kurz WA, Dymond CC, Stinson G et al (2008a) Mountain pine beetle and forest carbon feedback to climate change. Nature 452:987-990

Kurz WA, Stinson G, Rampley GJ et al (2008b) Risk of natural disturbances makes future contribution of Canada's forests to the global carbon cycle highly uncertain. Proc Natl Acad Sci 105:1551-1555

Landguth EL, Cushman SA (2010) CDPOP: An individual-based, cost-distance spatial population genetics model. Mol Ecol Resour 10:156-161

Lankau RA, Nuzzo V, Spyreas G, Davis AS (2009) Evolutionary limits ameliorate the negative impact of an invasive plant. Proc Natl Acad Sci U.S.A 106:15362-15367

Leger EA, Espeland EK (2010) Coevolution between native and invasive plant competitors: implications for invasive species management. Evol Appl 3:169-178

Lehan NE, Murphy JR, Thorburn LP, Bradley BA (2013) Accidental introductions are important source of invasive plants in the Continental United States. Am J Bot 100:1287-1293

Leishman MR, Gallagher RV (2016) Will alien plant invaders be advantaged under future climates? In: Canning-Clode J (ed) Biological invasions in changing ecosystems. De Gruyter Open Ltd, Warsaw/ Berlin, pp 368-388

Levinson DH, Fettig CJ (2014) Climate change: Overview of data sources, observed and predicted temperature changes, and impacts on public and environmental health. In: Pinkerton KE, Rom W (eds) Climate change and global public health. Springer-Verlag, New York, pp 31-49

Lewis DB, Castellano MJ, Kaye JP (2014) Forest succession, soil carbon accumulation, and rapid nitrogen storage in poorly remineralized soil organic matter. Ecology 95:2687-2693

Lindroth RL (2010) Impacts of elevated atmospheric $\mathrm{CO}_{2}$ and $\mathrm{O}_{3}$ on forests: phytochemistry, trophic interactions, and ecosystem dynamics. J Chem Ecol 36:2-21

Liu JP, Song MR, Horton RM, Hu YY (2013) Reducing spread in climate model projections of a September ice-free Arctic. Proc Natl Acad Sci 110:12571-12576

Lockwood JL, Cassey P, Blackburn T (2005) The role of propagule pressure in explaining species invasion. Trends Ecol Evol 20:223-228
Lombaert E, Estoup A, Facon B et al (2014) Rapid increase in dispersal during range expansion in the invasive ladybird Harmonia axyridis. J Evol Biol 27:508-517

Long SP, Ainsworth EA, Rogers A, Ort DR (2004) Rising atmospheric carbon dioxide: plants FACE the future. Annu Rev Plant Biol 55:591-628

Lovett GM, Weiss M, Leibhold AM et al (2016) Nonnative forest insects and pathogens in the United States: impacts and policy options. Ecol Appl 26:1437-1455

Lu X, Siemann E, He M et al (2015) Climate warming increases biological control agent impact on a non-target species. Ecol Lett 18:48-56

Lu X, Siemann E, He M et al (2016) Warming benefits a native species competing with an invasive congener in the presence of a biocontrol beetle. New Phytol 211:1371-1381

Mack RN, Erneberg M (2002) The United States naturalized flora: largely the product of deliberate introductions. Ann Mo Bot Gard 89:176-189

Mainali KP, Warren DL, Dhileepan K et al (2015) Projecting future expansion of invasive species: comparing and improving methodologies for species distribution modeling. Glob Chang Biol 21:4464-4480

Maines A, Knochel D, Seastedt T (2013) Biological control and precipitation effects on spotted knapweed (Centaurea stoebe): empirical and modeling results. Ecosphere 4:1-14

Maloy OC (1997) White pine blister rust control in North America: a case history. Annu Rev. Phytopathol 35:87-109

Manea A, Leishman MR, Downey PO (2011) Exotic C4 grasses have increased tolerance to glyphosate under elevated carbon dioxide. Weed Sci 59:28-36

Marco A, Lavergne S, Dutoit T et al (2010) From the backyard to the backcountry: how ecological and biological traits explain the escape of garden plants into Mediterranean old fields. Biol Invasions 12:761-779

Maron JL, Marler M (2008) Field-based competitive impacts between invaders and natives at varying resource supply. J Ecol 96:1187-1197

Maron JL, Vilà M, Bommarco R et al (2004) Rapid evolution of an invasive plant. Ecol Monogr 74:261-280

Martin TG, Murphy H, Liedloff A et al (2015) Buffel grass and climate change: a framework for projecting invasive species distributions when data are scarce. Biol Invasions 17:3197-3210

Mattson WJ Jr (1980) Herbivory in relation to plant nitrogen content. Annu Rev Ecol Syst 11:119-161

Mattson WJ Jr, Haack RA (1987) The role of drought in outbreaks of plant-eating insects. Bioscience 37:110-118

McDowell NG, Beerling DJ, Breshears DD et al (2011) The interdependence of mechanisms underlying climate-driven vegetation mortality. Trends Ecol Evol 26:523-532

McKenney DW, Pedlar JH, Lawrence K et al (2007) Potential impacts of climate change on the distribution of North American trees. Bioscience 57:939-948

McKeon CS, Weber MX, Alter SE et al (2016) Melting barriers to faunal exchange across ocean barriers. Glob Chang Biol 22:465-473

Meentemeyer R, Rizzo D, Mark W, Lotz E (2004) Mapping the risk of establishment and spread of sudden oak death in California. For Ecol Manag 200:195-214

Meentemeyer RK, Cunniffe NJ, Cook AR et al (2011) Epidemiological modeling of invasion in heterogeneous landscapes: spread of sudden oak death in California (1990-2030). Ecosphere 2:1-24

Meigs GW, Zald HSJ, Campbell JL et al (2016) Do insect outbreaks reduce the severity of subsequent forest fires? Environ Res Lett 11:045008

Melillo JM, Richmond TC, Yohe GW (eds) (2014) Climate change impacts in the United States: the third national climate assessment. U.S. Global Change Research Program, 841 p. https://doi. org/10.7930/J0Z31WJ2 
Metz MR, Frangioso KM, Meentemeyer RK, Rizzo DM (2011) Interacting disturbances: wildfire severity affected by stage of forest disease invasion. Ecol Appl 21:313-320

Metz MR, Frangioso KM, Wickland AC et al (2012) An emergent disease causes directional changes in forest species composition in coastal California. Ecosphere 3:1-23

Michener WK, Blood ER, Bildstein KL, Brinson MM, Gardner L (1997) Climate change, hurricanes and tropical storms, and rising sea level in coastal wetlands. Ecol Appl 7:770-801

Miller-Rushing AJ, Lloyd-Evans TL, Primack RB et al (2008) Bird migration times, climate change, and changing population size. Glob Chang Biol 14:1959-1972

Mooney HA, Cleland EE (2001) The evolutionary impact of invasive species. Proc Natl Acad Sci 98:5446-5451

Morehouse K, Johns T, Kaye J, Kaye M (2008) Carbon and nitrogen cycling immediately following bark beetle outbreaks in Southwestern ponderosa pine forests. For Ecol Manag 255:2698-2708

Morrison RG, Lownds NK, Sterling TM (1995) Picloram uptake, translocation, and efficacy in relation to water status of Russian knapweed (Acroptilon repens). Weed Sci 43:34-39

Morse LE, Kartesz JT, Kutner LS (1995) Native vascular plants. In: LaRoe ET, Farris GS, Puckett CE, Doran PD, Mac MJ (eds) Our living resources: a report to the nation on the distribution, abundance, and health of U.S. plants, animals, and ecosystems. U.S. Department of the Interior, National Biological Service, Washington, DC, pp 205-209

Mráz P, Tarbush E, Müller-Schärer H (2014) Drought tolerance and plasticity in the invasive knapweed Centaurea stoebe s.l. (Asteraceae): effect of populations stronger than those of cytotype and range. Ann Bot 114:289-299

Nave LE, Vance ED, Swanston CW, Curtis PS (2010) Harvest impacts on soil carbon storage in temperate forests. For Ecol Manag 259:857-866

Nave LE, Vance ED, Swanston CW, Curtis PS (2011) Fire effects on temperate forest soil C and N storage. Ecol Appl 21:1189-1201

Norberg J (2004) Biodiversity and ecosystem functioning: a complex adaptive systems approach. Limnol Oceanogr 49:1269-1277

Nuckolls AE, Wurzburger N, Ford CR et al (2009) Hemlock declines rapidly with hemlock woolly adelgid infestation: impacts on the carbon cycle of southern Appalachian forests. Ecosystems 12:179-190

Oliva J, Stenlid J, Martínez-Vilalta J (2014) The effect of fungal pathogens on the water and carbon economy of trees: implications for drought-induced mortality. New Phytol 203:1028-1035

Orwig DA, Thompson JR, Povak NA et al (2012) A foundation tree at the precipice: Tsuga canadensis health after the arrival of Adelges tsugae in central New England. Ecosphere 3:10

Orwig DA, Plotkin AAB, Davidson EA et al (2013) Foundation species loss affects vegetation structure more than ecosystem function in a northeastern USA forest. Peer J 1:e41

Parker IM, Rodriguez J, Loik M (2003) An evolutionary approach to understanding the biology of invasions: local adaptation and general purpose genotypes in the weed Verbascum thapsus. Conserv Biol 17:59-72

Parmesan C (2006) Ecological and evolutionary responses to recent climate change. Annu Rev. Ecol Evol Syst 37:637-669

Parmesan C, Yohe G (2003) A globally coherent fingerprint of climate change impacts across natural systems. Nature 421:37-42

Pearman PB, Guisan A, Broennimann O et al (2007) Niche dynamics in space and time. Trends Ecol Evol 23:149-158

Pearson RG, Dawson TP (2003) Predicting the impacts of climate change on the distribution of species: are bioclimate envelope models useful? Glob Ecol Biogeogr 12:361-371

Pearson DE, Ortega YK, Runyon JB et al (2016) Secondary invasion: the bane of weed management. Biol Conserv 197:8-17

Percy KE, Awmack CS, Lindroth RL et al (2002) Altered performance of forest pests under atmospheres enriched by $\mathrm{CO}_{2}$ and $\mathrm{O}_{3}$. Nature 420:403-407
Peterson AT (2003) Predicting the geography of species' invasions via ecological niche modeling. Q Rev. Biol 78:419-433

Peterson AT (2011) Ecological niche conservatism: a time structured review of evidence. J Biogeogr 38:817-827

Petitpierre B, Kueffer C, Broennimann O et al (2012) Climatic niche shifts are rare among terrestrial plant invaders. Science 335:1344-1347

Phillips BL, Shine R (2006) An invasive species induces rapid adaptive change in a native predator: cane toads and black snakes in Australia. Proc R Soc B 273:1545-1550

Phillips BL, Brown GP, Webb JK, Shine R (2006) Invasion and the evolution of speed in toads. Nature 439:803-803

Prado SS, Hung KY, Daugherty MP, Almeida RPP (2010) Indirect effects of temperature on stink bug fitness, via maintenance of gutassociated symbionts. Appl Environ Microbiol 76:1261-1266

Pritchard SG, Rogers HH, Prior SA, Peterson CM (1999) Elevated CO and plant structure: a review. Glob Chang Biol 5:807-837

Pyke CR, Thomas R, Porter RD et al (2008) Current practices and future opportunities for policy on climate change and invasive species. Conserv Biol 22:585-592

Raffa KF, Gregoire J-C, Lindgren BS (2015) Natural history and ecology of bark beetles. In: Vega FE, Hofstetter RW (eds) Bark beetles: biology and ecology of native and invasive species. Springer, London, $40 \mathrm{p}$

Rehfeldt GE, Tchebakova NM, Barnhardt LK (1999) Efficacy of climate transfer functions: introduction of Eurasian populations of Larix into Alberta. Can J For Res 29:1660-1668

Rehfeldt GE, Crookston NL, Sáenz-Romero C, Campbell EM (2012) North American vegetation model for land-use planning in a changing climate: a solution to large classification problems. Ecol Appl 22:119-141

Reichard SH, White P (2001) Horticulture as a pathway of invasive plant introductions in the United States. Bioscience 51:103-113

Reynolds C, Miranda NAF, Cumming GS (2015) The role of waterbirds in the dispersal of aquatic alien and invasive species. Divers Distrib 21:744-754

Richardson H, Nemeth DJ (1991) Hurricane-borne African locusts (Schistocerca gregaria) on the Windward Islands. Geo J 23:349-357

Richardson DM, Pysek P, Rejmanek M et al (2000) Naturalization and invasion of invasive plants: concepts and definitions. Divers Distrib 6:93-107

Rizzo DM, Garbelotto M, Hansen EM (2005) Phytophthora ramorum: Integrative research and management of an emerging pathogen in California and Oregon forests. Annu Rev. Phytopathol 43:309-335

Robinson EA, Ryan GD, Newman JA (2012) A meta-analytical review of the effects of elevated $\mathrm{CO}_{2}$ on plant-arthropod interactions highlights the importance of interacting environmental and biological variables. New Phytol 194:321-336

Rouault G, Candau J-N, Lieutier F et al (2006) Effects of drought and heat on forest insect populations in relation to the 2003 drought in Western Europe. Ann For Sci 63:613-624

Runyon JB, Butler JL, Friggens MM et al (2012) Invasive species and climate change (Chapter 7). In: Finch DM (ed) Climate change in grasslands, shrublands, and deserts of the interior American West: a review and needs assessment. General technical report RMRSGTR-285. U.S. Department of Agriculture, Forest Service, Rocky Mountain Research Station, Fort Collins, pp 97-115

Schneider RW, Hollier CA, Whitam HK et al (2005) First report of soybean rust caused by Phakopsora pachyrhizi in the continental United States. Plant Dis 89:774

Schwilk DW, Keeley JE, Knapp EE et al (2009) The National Fire and Fire Surrogate Study: effects of alternative fuel reduction methods on forest structure. Ecol Appl 19:285-304

Seastedt TR, Knochel DG, Garmoe M et al (2007) Interactions and effects of multiple biological control insects on diffuse and spotted knapweed in the Front Range of Colorado. Biol Control 42:345-354 
Seebens H, Essl F, Dawson W et al (2015) Global trade will accelerate plant invasions in emerging economies under climate change. Glob Chang Biol 21:4128-4140

Sheppard CS, Burns BR, Stanley MC (2014) Predicting plant invasions under climate change: are species distribution models validated by field trials. Glob Chang Biol 20:2800-2814

Shirk, AJ, Cushman SA, Waring KM et al (2018) Southwestern white pine (Pinus strobiformis) species distribution models project a large range shift and contraction due to regional climatic changes. Forest Ecol Manag 411:127-186

Simard M, Romme WH, Griffin JM, Turner MG (2010) Do mountain pine beetle outbreaks change the probability of active crown fire in lodgepole pine forests? Ecol Monogr 81:3-24

Six DL, Bentz BJ (2007) Temperature determines symbiont abundance in a multipartite bark beetle-fungus ectosymbiosis. Microb Ecol 54:112-118

Skinner K, Smith L, Rice P (2000) Using noxious weeds to prioritize targets for developing weed management strategies. Weed Sci 48:640-644

Smeets CJPP, Holzinger R, Vigano I et al (2009) Eddy covariance methane measurements at a Ponderosa pine plantation in California. Atmos Chem Phys 9:8365-8375

Smith SD, Strain BR, Sharkey TD (1987) Effects of $\mathrm{CO}_{2}$ enrichment on four Great Basin grasses. Funct Ecol 1:139-143

Smith SD, Huxman TE, Zitzer SF et al (2000) $\mathrm{CO}_{2}$ increases productivity and invasive species success in an arid ecosystem. Nature 408: 79-82

Smith AL, Hewitt N, Klenk N, et al (2012) Effects of climate change on the distribution of invasive alien species in Canada: a knowledge synthesis of range change projections in a warming world. Environ Rev 20:1-16

Sobek-Swant S, Crosthwaite JC, Lyons DB et al (2012) Could phenotypic plasticity limit an invasive species? Incomplete reversibility of mid-winter deacclimation in emerald ash borer Biol Invasions $14: 115-125$

Sorte CJ, Ibanez I, Blumenthal DM et al (2013) Poised to prosper? A cross-system comparison of climate change effects on native and non-native species performance. Ecol Lett 16:261-270

Stein BA, Flack SR (1996) America's least wanted: alien species invasions of U.S. ecosystems. The Nature Conservancy, Arlington, $31 \mathrm{p}$

Stephens SL, McIver JD, Boerner REJ et al (2012) Effects of forest fuel-reduction treatments in the United States. Bioscience 62: $549-560$

Stergiopoulos I, Gordon TR (2014) Cryptic fungal infections: the hidden agenda of plant pathogens. Plant-Microbe Interact 5:506

Story JM, Callan NW, Corn JG et al (2006) Decline of spotted knapweed density at two sites in western Montana with large populations of the introduced root weevil, Cyphocleonus achates (Fahraeus). Biol Control 38:227-232

Stroeve JC, Serreze MC, Holland MM et al (2012) The Arctic's rapidly shrinking sea ice cover: a research synthesis. Clim Chang 110:1005-1027

Sturrock RN, Frankel SJ, Brown AV et al (2011) Climate change and forest diseases. Plant Pathol 60:133-149

Suttle KB, Thomsen MA, Power ME (2007) Species interactions reverse grassland responses to changing climate. Science 315:640-642

Tabernero MT, Álvarez-Benedí J, Atienza J, Herguedas A (2000) Influence of temperature on the volatilization of triallate and terbutryn from two soils. Pest Manag Sci 56:175-180

Theoharides KA, Dukes JS (2007) Plant invasion across space and time: factors affecting non-indigenous species success during four stages of invasion. New Phytol 176:256-273

Thomas MB, Blanford S (2003) Thermal biology in insect-parasite interactions. Trends Ecol Evol 18:344-350
Thuiller W, Albert C, Araujo MB et al (2007) Predicting global change impacts on plant species' distributions: future challenges. Perspect Plant Ecol Evol Syst 9:137-157

Tobin PC, Nagarkatti S, Loeb G, Saunders MC (2008) Historical and projected interactions between climate change and insect voltinism in a multivoltine species. Glob Chang Biol 14:951-957

Travis JMJ, Dytham C (2002) Dispersal evolution during invasions. Evol Ecol Res 4:1119-1129

Turner KG, Fréville H, Riesberg LH (2015) Adaptive plasticity and niche expansion in an invasive thistle. Ecol Evol 5:3183-3197

Tylianakis JM, Didham RK, Bascompte J, Wardle DA (2008) Global change and species interactions in terrestrial ecosystems. Ecol Lett 11:1351-1363

Valachovic YS, Lee CA, Scanlon H et al (2011) Sudden oak deathcaused changes to surface fuel loading and potential fire behavior in Douglas-fir-tanoak forests. For Ecol Manag 261:1973-1986

van Asch M, Tienderen V, Peter H et al (2007) Predicting adaptation of phenology in response to climate change, an insect herbivore example. Glob Chang Biol 13:1596-1604

Verlinden M, Nijs I (2010) Alien plant species favoured over congeneric natives under experimental climate warming in temperate Belgian climate. Biol Invasions 12:2777-2787

Viana DS, Gangoso L, Bouten W, Figuerola J (2016) Overseas seed dispersal by migratory birds. Proc R Soc B 283:2015-2046

Vitousek PM (1994) Beyond global warming - ecology and global change. Ecology 75:1861-1876

Vose J, Clark J, Luce C, Patel-Weynand T (eds) (2016) Effects of drought on forest ecosystems: a comprehensive science synthesis. WO-GTR-93b. U.S. Department of Agriculture, Forest Service, Washington Office, Washington, DC, $289 \mathrm{p}$

Wainwright CE, Wolkovich EC, Cleland EE (2012) Seasonal priority effects: implications for invasion and restoration in semi-arid system. J Appl Ecol 49:234-241

Walsh J, Wuebbles D, Hayhoe K et al (2014) Appendix 3: climate science supplement. In: Melillo JM, Richmond TC, Yohe GW (eds) Climate change impacts in the United States: the third national climate assessment. Washington, DC: U.S. Global Change Research Program. Pages: 735-789

Walther GR, Roques A, Hulme PE et al (2009) Alien species in a warmer world: risks and opportunities. Trends Ecol Evol 24:686-693

Wand SJE, Midgley GF, Jones MH, Curtis PS (1999) Responses of wild $\mathrm{C}_{4}$ and $\mathrm{C}_{3}$ grass (Poaceae) species to elevated atmospheric $\mathrm{CO}_{2}$ concentration: a meta-analytic test of current theories and perceptions. Glob Chang Biol 5:723-741

Wang T, Hamann A, Yanchuck A, O’Neill GA, Aitkin SN (2006) Use of response functions in selecting lodgepole pine populations for future climates. Glob Chang Biol 12:2404-2416

Wang T, Campbell EM, O'Neill A, Aitken SN (2012) Projecting future distributions of ecosystem climate niches: uncertainties and management applications. For Ecol Manag 279:128-140

Watt AD, McFarlane AM (2002) Will climate change have a different impact on different trophic levels? Phenological development of winter moth Operophtera brumata and its host plants. Ecol Entomol 27:254-256

Weed AS, Ayres MP, Hicke JA (2013) Consequences of climate change for biotic disturbances in North American forests. Ecol Monogr 83:441-470

Westerling AL, Hidalgo HG, Cayan DR, Swetnam TW (2006) Warming and earlier spring increases western U.S. forest wildfire activity. Science 313:940-943

White PS, Pickett STA (1985) The ecology of natural disturbance and patch dynamics. Academic Press, Orlando, $472 \mathrm{p}$

Willis CG, Ruhfel BR, Primack RB et al (2010) Favorable climate change response explains non-native species' success in Thoreau's woods. PLoS One 5:e8878 
Winder M, Schindler DE (2004) Climate change uncouples trophic interactions in an aquatic ecosystem. Ecology 85:2100-2106

Wolkovich EM, Cleland EE (2011) The phenology of plant invasions: a community ecology perspective. Front Ecol Environ 9:287-229

Wolkovich EM, Cleland EE (2014) Phenological niches and the future of invaded ecosystems with climate change. AoB Plants 6:plu013

Wolkovich EM, Davis TJ, Schaefer H, Cleland EE, Cook BI, Travers SE, Willis CG, Davis CC (2013) Temperature-dependent shifts in phenology contribute to the success of exotic species with climate change. Am J Bot 100:1407-1421

Woods A, Coates KD, Hamann A (2005) Is an unprecedented Dothistroma needle blight epidemic related to climate change? Bioscience 55:761-769

Woods AJ, Martín-García J, Bulman L et al (2016) Dothistroma needle blight, weather and possible climatic triggers for the disease's recent emergence. For Pathol 46:443-452

Xu C-Y, Tang S, Fatemi M et al (2015) Population structure and genetic diversity of invasive Phyla canescens: implications for the evolutionary potential. Ecosphere 6:162
Yuan JS, Himanen SJ, Holopainen JK et al (2009) Smelling global climate change: mitigation of function for plant volatile organic compounds. Trends Ecol Evol 24:323-331

Zavala JA, Casteel CL, DeLucia EH et al (2008) Anthropogenic increase in carbon dioxide compromises plant defense against invasive insects. Proc Natl Acad Sci 105:5129-5133

Zelikova TJ, Hufbauer RA, Reed SL et al (2013) Eco-evolutionary responses of Bromus tectorum to climate change: implications for biological invasions. Ecol Evol 3:1374-1387

Ziska LH, Dukes JS (2011) Weed biology and climate change. WileyBlackwell, Ames, 235 pages

Ziska LH, Teasdale JR, Bunce JA (1999) Future atmospheric carbon dioxide may increase tolerance to glyphosate. Weed Sci 47:608-615

Ziska LH, Faulkner S, Lydon J (2004) Changes in biomass and root: shoot ratio of field-grown Canada thistle (Cirsium arvense), a noxious, invasive weed, with elevated $\mathrm{CO}_{2}$ : implications for control with glyphosate. Weed Sci 52:584-588

Ziska LH, Reeves JB III, Blank B (2005) The impact of recent increases in atmospheric $\mathrm{CO}_{2}$ on biomass production and vegetative retention of cheatgrass (Bromus tectorum): implications for fire disturbance. Glob Chang Biol 11:1325-1332

Open Access This chapter is licensed under the terms of the Creative Commons Attribution 4.0 International License (http://creativecommons. org/licenses/by/4.0/), which permits use, sharing, adaptation, distribution and reproduction in any medium or format, as long as you give appropriate credit to the original author(s) and the source, provide a link to the Creative Commons license and indicate if changes were made.

The images or other third party material in this chapter are included in the chapter's Creative Commons license, unless indicated otherwise in a credit line to the material. If material is not included in the chapter's Creative Commons license and your intended use is not permitted by statutory regulation or exceeds the permitted use, you will need to obtain permission directly from the copyright holder. 